\title{
Science Rewritten to Accommodate its Origin
}

\section{Michael T Deans}

\section{Introduction and abstract:}

A ferroelectric phase transition in ice at $\sim 72 \mathrm{~K}$ releases latent energy as $\lambda \sim 4 \mu$ infrared laser light, 'ice light', energizing selected targets. Polarized by multiple reflection [22], it photophosphorylated deoxynucleotides, turning tropical waters into a noodle soup of chiral DNA. tRNA analogues 'transport DNAs', tDNAs embedded in Alexander Oparin's lightning-charged coacervates [23] formed H-bond lined pores. Absorbed ice light created an electric field, driving a ratchet mechanism which actively imported charged carrier-substrate complexes.

All life descends from the first cell to replicate a tDNA and depends on the trace element requirements of 64 tDNA variants. They constitute life's atomic alphabet, their substrate complexes its molecular vocabulary. The inviolable rules of active transport predate protein synthesis and enzyme catalysis. Medical, veterinary and pharmaceutical data are consistent with nine independent metabolic pathways. My account of water transport contradicts Peter Mitchell's chemiosmotic hypothesis [24]. Trace element deficiencies disabling active transport cause most mental and physical maladies, supplements could prevent them.

'Differentiation DNAs', dDNAs selecting tDNAs control cells' substrate uptake, c.f. mRNAs encode protein synthesis by selecting tRNAs. Barrels of a-helices [25] supplement tDNAs and tDNA genetics governs familial inheritance of metabolic disorders, a minion-based data base would facilitate their diagnosis. Trace element supplements would prevent heart attacks, strokes, cancers, diabetes, Alzheimer's dementia and rarer conditions, improve health and reduce NHS expenditure.

The 189*18 arrays of proton ordered H-bonds connecting amino acid $\omega$-amines to DNA phosphates on 'minions' control metabolism, serve as biological clocks, memory stores and personality biased brain chips and are basis for reinterpreting scientific dogma. Nine parallel metabolic pathways reflecting their 9-fold symmetry control metabolism. Oscillating H-bonds accelerate protons along minion tunnels, driving molecular scale nuclear fusion. Trapping the $\gamma$-rays released at source could solve current energy and pollution crises. Computers and data-bases modelled on minions promise human-friendly artificial intelligence satisfying Turing's criteria [26].

Comparing cybernetics, psychology and traditional wisdom suggested 'minions', the name connotes subservience. They comprise 189 anti-parallel $\beta$-sheet hairpins [27] with alternate neutral and basic amino acid residues and proline forming an asymmetric U-bend. They hold nine DNA base pairs flat, forming a nine-coil abacus. Evolved to pack DNA on chromosomes for efficient replication, they underpin philosophy and science, account for human intelligence and resolve many questions. My mutually consistent arguments contradict accepted dogma.

Axioms

- Linus Pauling showed ice crystals are disordered, the four H-bonds interconnecting water molecules have random orientations. Some of the 16 known ice forms [28] have orderly bonds. 


\section{International Journal of Innovative Research in Medical Sciences (IJIRMS) \\ ISSN (Online): 2455-8737, page No. 160 to193 \\ Volume 01, Issue 05, July 2016}

An ordered variant of the cubic structure would be anticipated after crystallization in liquid nitrogen, confirmed by recent reports of a ferroelectric transition at $72 \mathrm{~K}$ in 'ice XIc' [29]. Ferroelectric transitions release latent energy as laser light, released infrared laser light might be detectable, Figs $1 \mathrm{a}, \mathrm{b}$ and $\mathrm{c}$.

- The wavelength, $\lambda \sim 4 \mu$ and latent energy of ice light may be estimated and their equality with those of the phosphodiester bond in ATP be confirmed. The dimensions of sarcomeres in striated muscle, mitochondria, chloroplast grana and centrioles accommodating muscle contraction, Kreb's cycle [30], photosynthesis and powering chromosome separation at cell division afford resonant cavities enabling photochemical energy conversions, Figs d, e, f and g; testable using available laser sources. Iced aircraft wings reflect $\sim 4 \mu$ light [31], ice in clouds and on the surface multiply reflecting it would deliver polarized light generated on Earth's poles to tropical waters. Since water absorbs at $4 \mu$, photochemical activity is restricted to surface resident molecules, polarization determines chiral [32] selection, Fig $1 \mathrm{~h}$.

- Deoxynucleotides concentrated by evaporation would polymerize to DNA, some probably forming tRNA analogues, tDNAs. The $\sim 4 \mu$ driven ratchet mechanism, Fig 1i, actively transporting ionic carrier-substrate complexes through cell membranes might be emulated. Theoretical analysis could establish its efficiency and compare its probability with those of deep sea vents [33], panspermia [34] and other proposals.

\section{Origin of life}

In 1967, ice crystallizing in liquid nitrogen distorted a silica helium thermometer bulb, suggesting a proton-ordered variant of cubic ice forming on its surface with its molecular dipoles aligned had contracted on cooling to accommodate water molecules' irregular tetrahedral shape. Sixteen forms of ice are now known, doped ice Ih has recently been shown to re-crystallize slowly as ferroelectric variant of ice Ic, ice XIc with a phase transition at $72 \mathrm{~K}$, Figs $2 \mathrm{a}$ and $b$. It has a small stability range and confirms my original proposal of 'ice It'. Verifying that the phase transition releases latent energy as ice light', $\lambda \approx 4 \mu$ wavelength infrared laser light would counter scepticism. Its existence doesn't contravene Pauling's proposal that hexagonal ice with its $\mathrm{H}$-bonds randomly $\mathrm{O} \cdots \mathrm{H}-\mathrm{O}$ or $\mathrm{O}-\mathrm{H} \cdots \mathrm{O}$ retains entropy at $0 \mathrm{~K}$ [35].

Observed temperatures at Mercury's poles and on the moons of Jupiter [36] are cold enough for ice XIc to form, primordial Earth's O2-free atmosphere permitted polar liquid nitrogen to coexist with warm tropical waters. Pools of liquid $\mathrm{N} 2$ forming on Earth's poles during a primordial ice age boiled when snow, sleet or hail fell. Ice crystallizing at the surface formed proton ordered ice, its low entropy explains life's emergence from chaos. Random and cyclic temperature fluctuations driving its ferroelectric phase transition released latent energy as ice light. Reflection by ice in clouds and on Earth's surface like Marconi's trans-Atlantic radio waves delivered polarized light to tropical waters, Fig $1 \mathrm{~h}$. Nucleotide synthesis has been demonstrated. [37] Their phosphodiester bonds selectively absorbed ice light, polymerizing to form a pre-biotic DNA 'noodle soup'. DNA's greater stability than RNA favours it as life's precursor [38]: RNA's extra $\mathrm{OH}$ group prevents minion formation. 

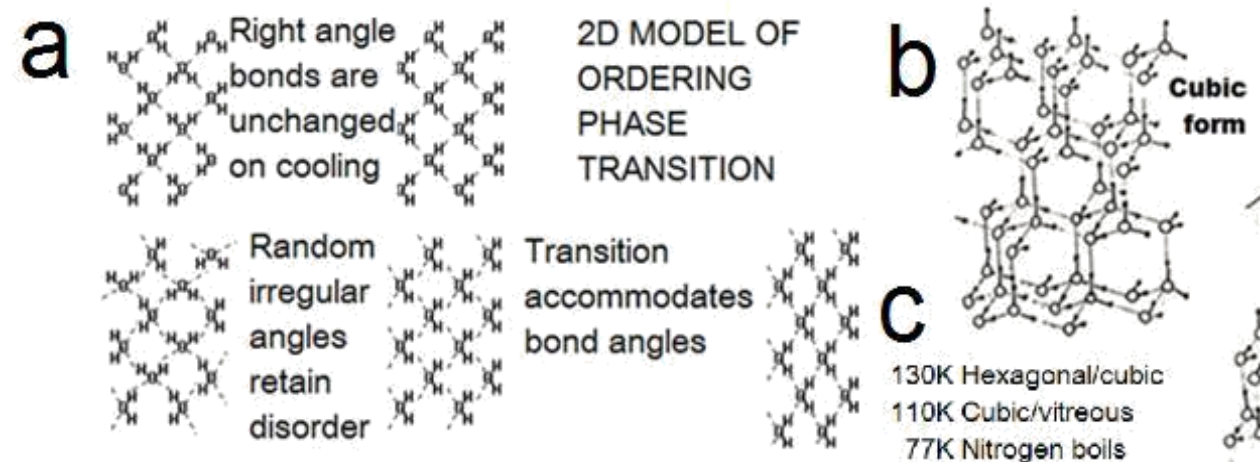

TRANSITION

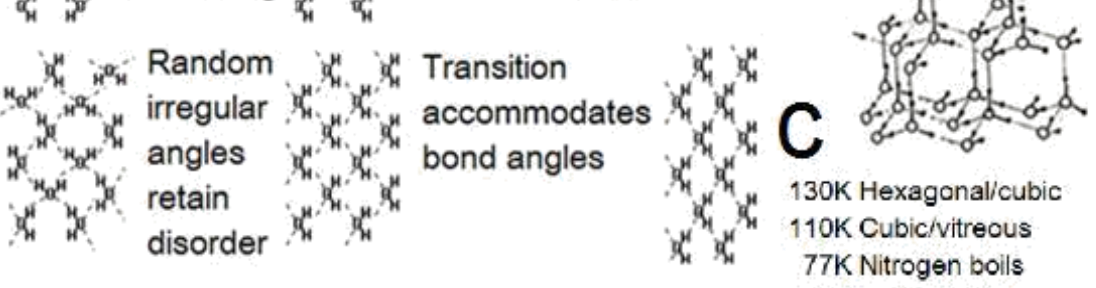

$72 \mathrm{~K}$ Ferroelectric

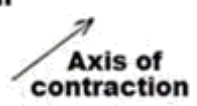

Tetragonal 89 do

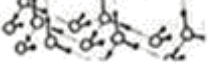
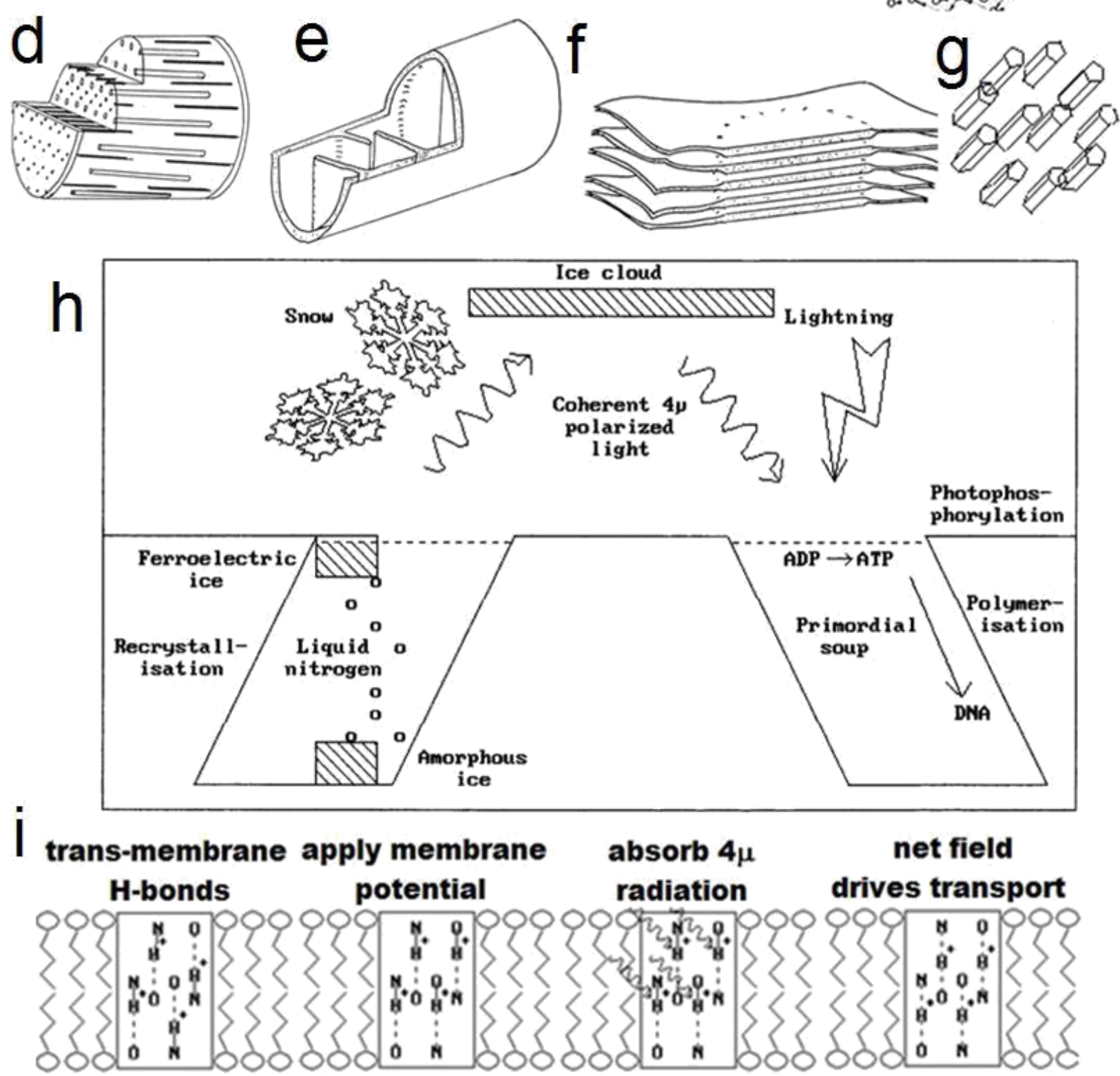

Figure 1. a and b Ordering phase transition, 2D and 3D, c Transition temperatures, $d$ Sarcomere, e

Mitochondrion, f Chloroplast granum, g Centriole, h Origin of life, i Transport mechanism. 

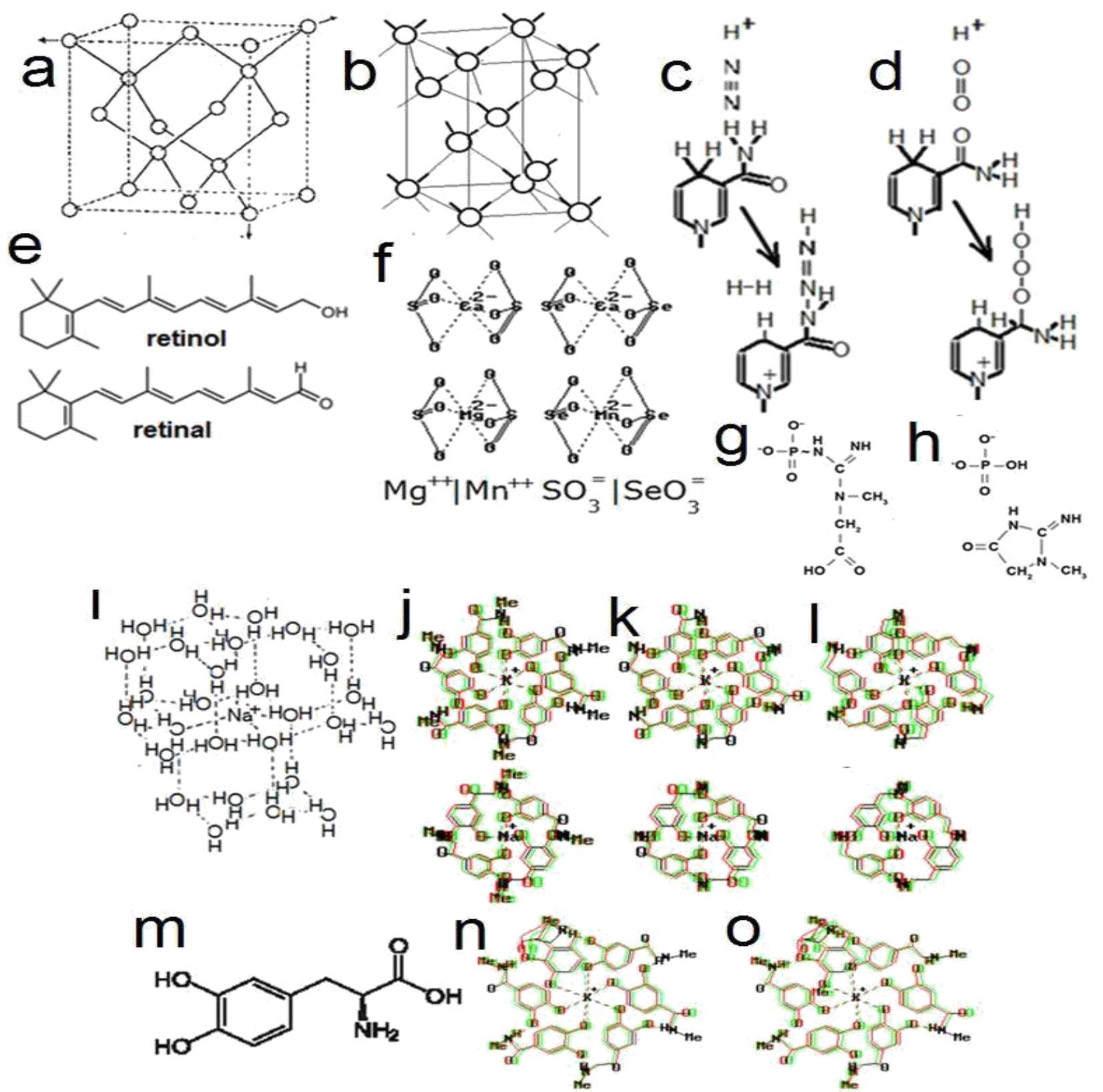

Figure 2. a Ice Ic, b Ice XIc, c Nitrogen fixation, $d$ Oxygen release, e Vitamin A isomers, f Sulphite and selenite exchange $\mathrm{Mg}^{++}$and $\mathrm{Mn}^{++}$for $\mathrm{Ca}^{++}$, g Creatine, $\mathrm{h}$ Creatinine, i Sodium hydrate, $\mathrm{j}$, $\mathrm{k}$ and $\mathrm{l}$ Adrenalin, noradrenalin and dopamine form 6-member rings round $\mathrm{K}^{+}$, 4-member round $\mathrm{Na}^{+}, \mathrm{m}$ LDopa, $n$ Morphine, o Codeine.

Molecules with particular chirality absorb polarized light preferentially, basis for the handedness of biological chemistry highlighted by the thalidomide disaster [39]. Transport DNAs, tRNA analogues, feature an H-bond lined 'hole' [40]. Via an ice light driven ratchet mechanism, they propelled trace element based charged carrier-substrate complexes through Oparin's coacervate membranes [41]. Electric storms charged the proto-cells, polarizing the $\mathrm{H}$-bonds and directing ion flow. Catecholamines exchanging potassium for sodium ions in 2:3 ratio [42] now maintains membrane potential. Trace elements constitute life's atomic alphabet, a shortlist of substrates its molecular vocabulary. Overwhelming evidence supports my contention 


\section{International Journal of Innovative Research in Medical Sciences (IJIRMS) \\ ISSN (Online): 2455-8737, page No. 160 to193 \\ Volume 01, Issue 05, July 2016}

that tDNAs persist in modern life, ATP hydrolysis replaces ice light.

Life's chemistry evolved before protein synthesis and enzyme catalysis, establishing inviolable rules. Barrels of $\alpha$-helices [43] opening and closing fine-tuning modern life are less efficient than tDNAs. A complement of 2,000 tDNAs per cell underpinning all biological systems has yet to be detected. Life started when coacervates concentrating nucleotides promoted tDNA replication. Those acquiring mutants enjoyed a diverse diet. Dynamic equilibrium in the primordial soup predated intra-cellular metabolism. A tDNA and nicotinamide enable oxygen production [44] and nitrogen fixation [45] fostering amino acid synthesis, Figs $2 \mathrm{c}$ and d. Our oxygenated atmosphere and photosynthesis may predate protein synthesis.

\section{Trace element nutrition}

tDNAs afford a strong electric field, excluding water. A lock-and-key match with its outer rim permits entry. All life's components are synthesized from ionic complexes between trace elements and a short list of substrates with various shapes. Zeolites, Buckminsterfullerenes and other molecular cages [46] might enable in vitro verification of their structures. Porphyrins harvest light of various wavelengths, vitamin $\mathrm{A}$ isomer retinal [47] and vitamin E, $\alpha$-tocopherol [48] carry it through the membrane along conjugated single and double bonds, (-C-C=C-)n as solitons [49], Fig 2e. It drives the photochemical synthesis of carrier complexes. Sulphite, selenite, pyrophosphate and silicon hexafluoride, carriers for magnesium, manganese, arginine and apatite are assembled this way, Fig $2 \mathrm{e}$.

I've identified nine independent, mathematically 'orthogonal' metabolic pathways controlling: motility, sensitivity, excretion, respiration, growth, skeletal development, assimilation, reproduction and blood pressure control, Table 1. Trace elements' roles as enzyme cofactors can mask those as carrier components. Technical advances, religious taboos and food processing: agrochemicals (fertilizers, weed killers and pesticides [50]), industrial pollution (sulphur and nitrogen oxides [51], mercury [52] and pharmaceutical waste) and pursuit of hygiene (water purification, fermentation and heattreatment) reduce trace element availability.

Table 1. Nine independent biological pathways

\begin{tabular}{|r|l|l|l|l|l|}
\hline$\#$ & SYSTEM & TISSUE & CARRIERS & SUBSTRATE & PATHOLOGY \\
\hline 1 & Motility & muscle & $\mathrm{SO}_{3}{ }^{=}$ & $\mathrm{Ca}^{++}$and $\mathrm{Mg}$ & spasticity \\
\hline 2 & Sensitivity & nerve & catecholamines & $\mathrm{Na}^{+}$and $\mathrm{K}^{+}$ & depression \\
\hline 3 & Excretion & kidney & $\mathrm{Mn}^{++}$ & $\mathrm{Salt}^{++}$ & kidney failure \\
\hline 4 & Respiration & lung & $\mathrm{I}^{+}$ & $\mathrm{O}_{2} . \mathrm{H}_{2} \mathrm{O}$ & bipolar \\
\hline 5 & Growth & liver & $\mathrm{Cu}^{++}$ & amino acids & growth defects \\
\hline 6 & bones and teeth & bone & $\mathrm{SiF}^{+}{ }^{+}$and $\mathrm{AlF}_{6}{ }^{\equiv}$ & $\mathrm{Mn}^{++}$and apatite & Alzheimer's \\
\hline 7 & Assimilation & gut & $\mathrm{Zn}^{++}$ & $\beta$-Dglucose & diabetes \\
\hline 8 & Reproduction & gonads & $\mathrm{Ag}^{+}$and arginine & pyrophosphate & cancer \\
\hline 9 & blood pressure & heart & $\mathrm{SeO}_{3}{ }^{=}$and MevP & Water & heart disease \\
\hline
\end{tabular}

experience guided my initial investigations.

Large scale double-blind clinical trials are Familial inheritance of orphan conditions, expensive, unethical and contentious, veterinary 


\section{International Journal of Innovative Research in Medical Sciences (IJIRMS) \\ ISSN (Online): 2455-8737, page No. 160 to193 \\ Volume 01, Issue 05, July 2016}

traditional herbal remedies and drug side-effects gave better clues than statistical surveys. Prevailing theories are often based on statistical correlations have been discredited, e.g. substances classed as oxidants destroying free radicals [53] include glutathione, vitamins $\mathrm{A}, \mathrm{C}$ and $\mathrm{E}$ with roles I've elucidated. Mantra such as five a day [54], high fibre [55], avoiding saturated fats [56] and eating oily fish [57] divert attention.

Although food labelling, sell-by dates, organic farming, vegan diets and eschewing genetically modified crops are environmentally friendly, they may inadvertently endanger consumers. Pharmaceutical and health food manufacturers exploit the adverse publicity their advocates create. School dinners and canteen meals can aggravate orphan conditions. Support groups recommend dietary restrictions for their management. Superficial health checks and repeat prescriptions can have adverse long-term effects. Vaccinations, public hygiene and supplement distribution are government responsibilities. Inherited disorders need attention, not eugenics. Mental health conditions related to physical disorders also benefit from attention to diet.

\section{Motility}

The liver creates glutathione and retinal conducts energy as solitons to oxidise it, forming sulphite, $\mathrm{SO}_{3}{ }^{2}$. Acid conditions inhibit this, causing cramps [58]. $\mathrm{SO}_{3}=$ exchanges $\mathrm{Mg}^{++}$for $\mathrm{Ca}^{++}, \mathrm{Mg}^{++}$ catalyzes ATP hydrolysis, releasing $\mathrm{Pi} \sim \mathrm{Pi}$ bond energy as $\lambda \sim 4 \mu$ photons, life's energy currency, Fig 2 f. Selenite, $\mathrm{SeO}_{3}{ }^{=}$performs the same function for $\mathrm{Mn}^{++}$for Blood pressure control. All mechanical energy coupling involves resonant cavities for $\lambda$, more efficient than any process subject to thermodynamics [59]. Energy generated by centrioles' nine components affording such cavities, is transmitted along the nine conjugated $\mathrm{H}$-bond chains of spindle fibres' three $\alpha$-helices $\mathrm{CO}_{2}+\mathrm{H}_{2} \mathrm{O} \leftrightarrow \mathrm{HCO}_{3}^{-}+\mathrm{H}^{+}$. driving proton currents round chromosomes' minion coils, creating alternating magnetic forces with frequencies determined by chromosome length, causing their mutual repulsion at cell division [60]. Silver, Ag mediates high energy phosphate transport by creatine and creatinine replenishing ATP for sustained muscle contraction [61], Figs $2 \mathrm{~g}$ and h, c.f. water transport.

\section{Sensitivity}

Nerve transmission transmits pain, catecholamines exchange $\mathrm{Na}^{+}$for $\mathrm{K}^{+}$at synapses. $\mathrm{Na}^{+}$ions have the same shape and size as $\mathrm{H}_{2} \mathrm{O}$, forming hydrates possibly as large as $\mathrm{Na}^{+} .28 \mathrm{H}_{2} \mathrm{O}$ [62], Fig $2 \mathrm{i}$ making the cell sap viscous and slowing cell chemistry. Substituting $\mathrm{K}^{+}$binds less water, increasing metabolic rate, accounting for the 'fight or flight' reaction [63], reflex response to danger, Figs $2 \mathrm{j}, \mathrm{k}$ and 1 . Catecholamines form 4-member rings round $\mathrm{Na}^{+}$and 6 -member rings round $\mathrm{K}^{+}$, exchanging $3 \mathrm{Na}^{+}$for $2 \mathrm{~K}^{+}$and closing synapses [64], enabling pain transmission (see Minions) between nerve fibres.

Substituting codeine or morphine for adrenalin makes larger complexes, Fig 2n, o, blocking the tDNA pump and preventing pain transmission [65]. Pain sensitivity increases when more tDNAs are enrolled to compensate, explaining drug addiction. Differentiated brain areas employ different catecholamines (adrenaline, noradrenaline or dopamine), LDopa, Fig 2m, supplements counteract Parkinson's disease [66].

\section{Excretion}

Aldosterone, angiotensin, rennin, histamine and aspirin mediate salt transport, controlling acidity and ionic strength. Angiotensin delivers $\mathrm{Mn}$, its chlorides: $\mathrm{MnCl}_{3}{ }^{-}, \mathrm{MnCl}_{4}{ }^{=}$and $\mathrm{MnCl}_{6}{ }^{4-}$ excrete salt in urine, sweat and tears. The chloride shift [67] exchanges $\mathrm{HCO}_{3}{ }^{-}$for $\mathrm{Cl}^{-}$. Zn-dependent carbonic anhydrase catalyzes $\mathrm{pH}$ control: 

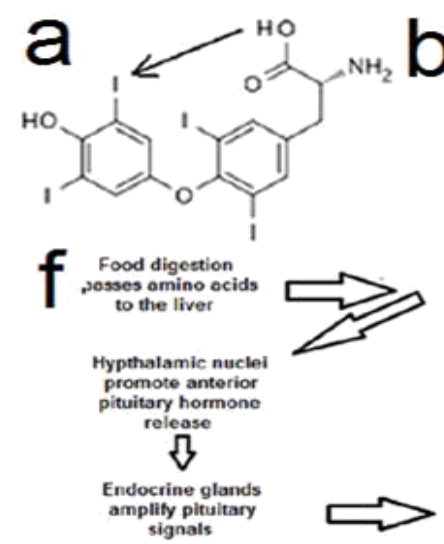

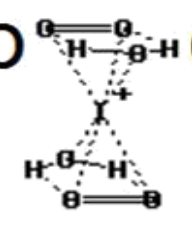

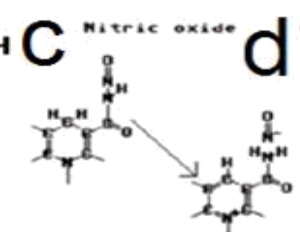

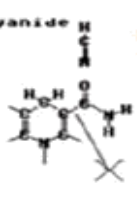<smiles>[CH-][PH3]</smiles>

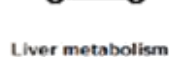

Ulverimetabolism
redistributes them in nine balanced

अ Tissues change
amino acid
balance iิ Homeostasis
maintains: maintains:
balance

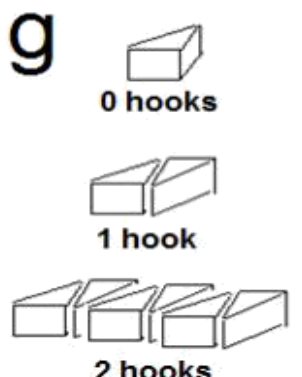

2 hooks

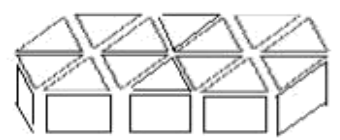

3 hooks

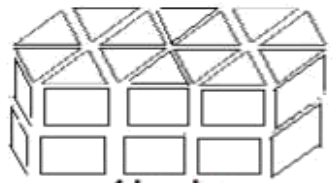

4 hooks

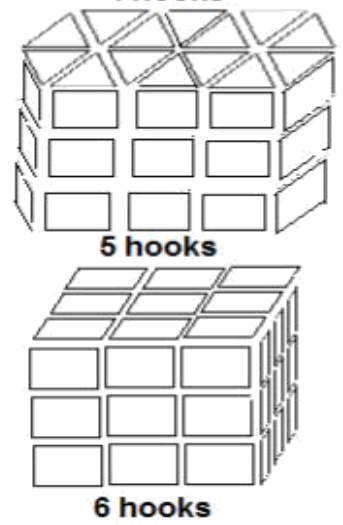

$\mathrm{h}$
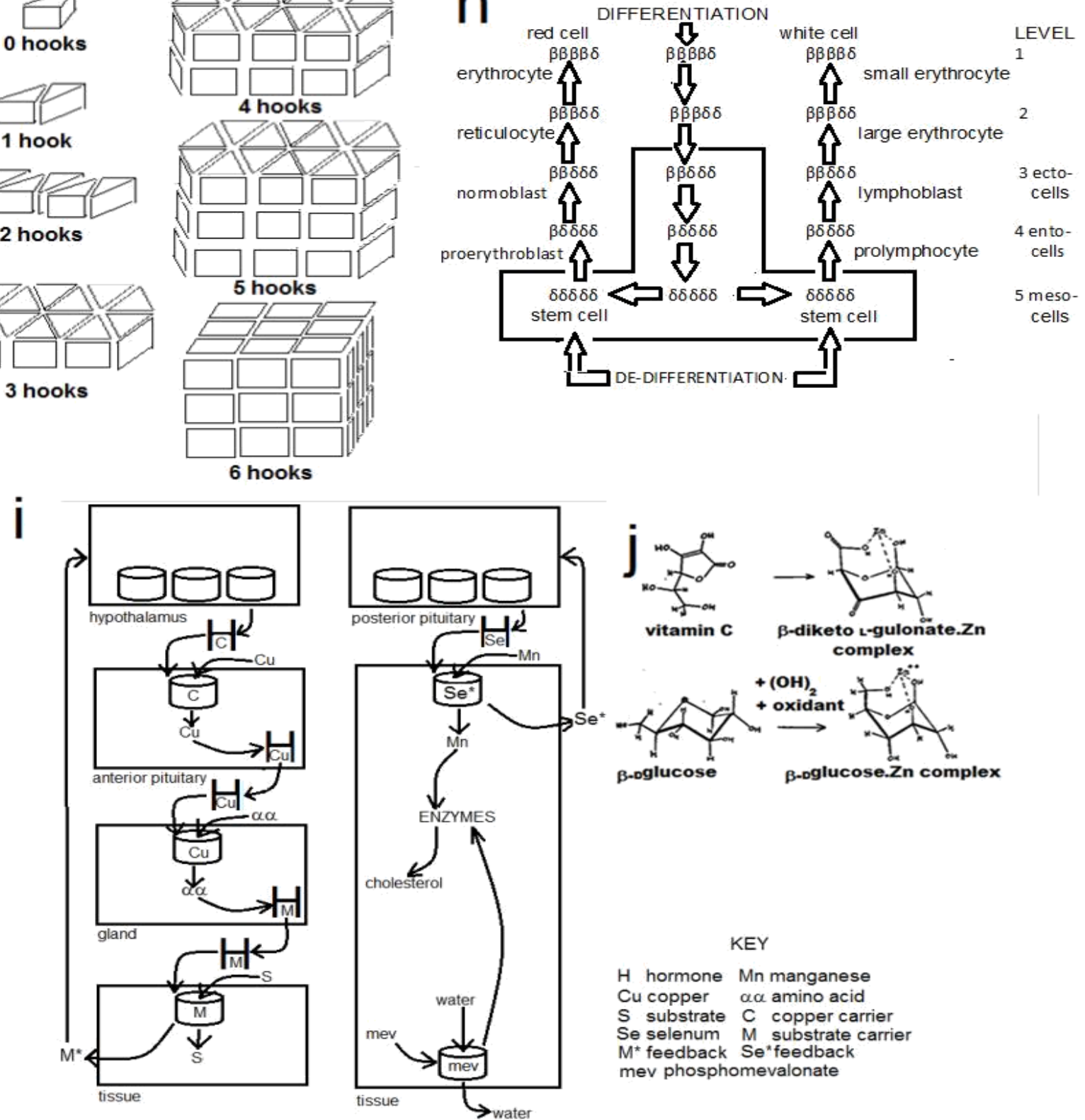

complex

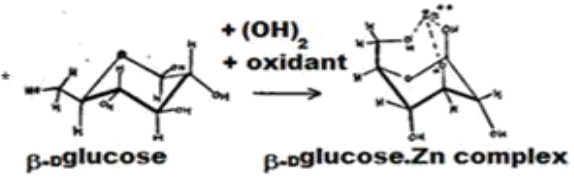

KEY

$H$ hormone Min manganese

Cúcopper occamino acid

S substrate C copper carrier

Se selenum $M$ substrate carrier

$M \ddagger$ feedback Selfeedback

mev phosphomevalonate

Figure 3. a Thyroxin delivers $\mathrm{I}^{+}, \mathrm{b} \mathrm{I}^{+} . \mathrm{O}_{2} \cdot \mathrm{H}_{2} \mathrm{O}$ complex, c NO release, d HCN toxicity, e Ethylene release, $f$ Liver balances amino acids, $g$ Hooks determine tissue morphology, $h$ Five stages of differentiation, i Signal amplification,j Lgulonate and ßDglucose bind zinc. 


\section{International Journal of Innovative Research in Medical Sciences (IJIRMS) \\ ISSN (Online): 2455-8737, page No. 160 to193 \\ Volume 01, Issue 05, July 2016}

\section{Respiration}

$\mathrm{O}_{2}$ cannot diffuse through unit membranes [68], lung surfaces exchange it with $\mathrm{CO}_{2}$ and erythrocytes convey it bound to haemoglobin. The thyroid glands load thyroxin with iodine, released as iodinium, $\mathrm{I}^{+}$, carrier for oxygen hydrate, $\mathrm{O}_{2} \cdot \mathrm{H}_{2} \mathrm{O}$ [69], iodine is recycled as $\mathrm{I}^{-}$, Figs $3 \mathrm{a}$ and b. Iodine protects littoral seaweeds against tidal $\left[\mathrm{O}_{2}\right]$ fluctuations [70]; their purple and yellow colours correspond with those of $\mathrm{I}^{+}$and $\mathrm{I}^{-}$.

Bacterial tDNAs accelerate protons, attaching $\mathrm{N}_{2}$ to nicotinamide in NAD, illustrating tDNA binding a nucleotide, releasing $\mathrm{H}_{2}$ and fixing $\mathrm{N}_{2}$ more efficiently than the Haber process [71], Fig2c. A parallel reaction in plants releases $\mathrm{O}_{2}$, equivalent to the photolysis of water, Fig 2d, accounting for its presence in Earth's atmosphere [72]. NO controlling vasodilation [73], Fig 3c, $\mathrm{HCN}$ and $\mathrm{CO}$ block them, Fig $3 \mathrm{~d}$ and ethylene generation [74], Fig 3e, employ similar processes.

Iodine deficiency causes goiter, swollen thyroids [75]. Water accompanying $\mathrm{I}^{+}$accumulating in the eyes causes exopthalmos [76]. Bipolar disorder [77], aka manic depression, arises when a mutant tDNA disrupts nerve cell oxygenation, excess and deficient $\mathrm{O}_{2}$ cause mania and depression respectively. $\mathrm{Li}^{+}$, diagonally related to $\mathrm{I}^{+}$in the periodic table, stabilizes $\mathrm{O}_{2}$ transport, controlling mood swings. Familial inheritance by 1 in 7 siblings may account for the 'seventh son of a seventh son' myth, it disobeys Mendel's laws [78].

\section{Growth}

Copper binds amino acids, c.f. Biuret test [79]. Transfer RNAs in protein synthesis deliver them across the endoplasmic reticulum to ribosomes [80] using the same mechanism as tDNAs. Amino acids from protein digestion pass to the liver for inter-conversion, ensuring the brain receives a balanced mixture, Fig 3f. Growth hormone somatotropin distributes $\mathrm{Cu}$, activating hypothalamic hormone production [81]. Its nine components relay them to the nine matching parts of the anterior pituitary gland [82] which distribute further growth hormones, somatomedins, supplying endocrine glands with $\mathrm{Cu}$. Their hormones balance tissue development. This cascade effectively amplifies a single molecular signal sufficiently to alert all body cells [83], Fig 3i. 'A little knowledge is a dangerous thing', wrote Alexander Pope, should biotechnologists create synthetic tDNAs without appreciating their dual roles, Mary Shelley's Frankenstein prophecy could be realized.

Stem cells [84] have a full complement of 'differentiation DNAs'. dDNAs selecting tDNAs is analogous to mRNAs selecting tRNAs for protein synthesis. Their balanced diet enables all types of metabolism. During the blastulation and gastrulation phases of cell division [85], cells facing the empty vacuole are starved of nutrients. Their tDNA pumps run dry and overheat, displacing adenylcyclase driving substrate transport in favour of guanylcyclase [86]. The tDNAs feed it with amino acids, assembling membrane 'hook' proteins. Nutrient imbalance causes differentiation [87], the hook proteins bind sister cells together to form a tissue. Five differentiation stages create all tissue types, Fig 3h. Biotechnologists' patented alchemy mimics this process.

Hook count determines tissue shapes, Fig 3g. Stem cells have none, eggs, sperm and leucocytes one hook, spirogyra filaments two, sponge sheets three and simple worms four. Higher organisms' tissues are combinations of cells with up to five hooks, their growth is limited. Proof of my Five hook theorem, 3D equivalent of the Four colour mapping theorem [88], would encourage researchers to take my other predictions seriously. Carcinogenic chemicals and radiation can promote a sixth hook to form, allowing the unlimited 


\section{International Journal of Innovative Research in Medical Sciences (IJIRMS) \\ ISSN (Online): 2455-8737, page No. 160 to193 \\ Volume 01, Issue 05, July 2016}

growth characteristic of cancers and tumours. Their nuclear DNA is unchanged, contrary to standard assumptions. Immune system white cells, leucocytes have an armoury of single hooks. These match the extra hook and devour the aberrant growth.

Copper supplements control growth disorders acromegaly, dwarfism and gigantism, attributable to mutant tDNAs and may ameliorate arthritis [89]. $\mathrm{Cu}$ coil contraceptives compete with zinc, preventing sperm acquiring sufficient glucose to reach their targets. The mythology of Libran balance and Virgoan justice is food for thought: temperance, birth control, and wise judgement have much to contribute to our future welfare. $\mathrm{Cu}$ accumulating in the eye causes Wilson's disease [90].

\section{Bones and teeth}

Skeleton maintenance involves silicon hexafluoride [91], $\mathrm{SiF}_{6}{ }^{=}$carrying calcium phosphate, Fig 4a. Calcium phosphate occurs in apatite and fluorapatite [92], $\mathrm{Ca}_{10}\left(\mathrm{PO}_{4}\right)_{6}(\mathrm{OH})_{2}$ and $\mathrm{Ca}_{10}\left(\mathrm{PO}_{4}\right)_{6}(\mathrm{~F})_{2}$. The stability of 'Blue John', fluorspar [93], CaF2 illustrates the strong affinity between calcium and fluorine. Vitamin D stores UV light with wavelength $\sim 265 \mathrm{~nm}$ [94], matching that needed to create $\mathrm{Si} \sim \mathrm{F}$ bonds [95]. Retinal transfers it as solitons, driving $\mathrm{SiF} 6=$ assembly, Fig 4b:

$$
\mathrm{SiO}_{2}+6 \mathrm{~F}^{-}+4 \mathrm{H}^{+}+\mathrm{UV} \text { light } \rightarrow \mathrm{SiF}_{6}{ }^{=}+2 \mathrm{H}_{2} \mathrm{O} \text {. }
$$

Both thyroid and parathyroid glands incorporate halides to hormones, they probably evolved in parallel [96]. Parathyroid hormone is secreted continuously [97], preventing hazardous Faccumulation in the gland. Acid conditions promote $\mathrm{SiF} 6=$ synthesis, acidity arising at menopause and in kidney failure causes brittle bones, osteoporosis [98]. Alkaline phosphatase assays assess bone pathology.
Acid air pollution sulphur or nitrogen oxides [99], SOx or NOx and tobacco smoke acidify the cavity behind the nose, promoting inappropriate $\mathrm{SiF} 6=$ synthesis. If it passes along olfactory nerves to the brain, its breakdown releases F-, causing Alzheimer's disease [100]. Assuming tDNAs orchestrate protein folding [101], the sensitivity of H-bonds to F- accounts for protein tangles [102]. Those characterizing prion diseases [103] may reflect mutant tRNAs misinterpreting mRNA sequences, defective tRNAs embedded in the product rendering them infectious.

Phosphate is scarce for plants; diatomaceous earth [104] preserves their silica $\mathrm{SiO}_{2}$ hard parts, created via the same substrate-carrier complex. Acid air pollution enters leaves via stomata, preventing its production and causing leaf-fall. Since liming the soil had no effect [105], interest in regulating the pollution was sidelined. Controlling acid air pollution and incorporation of fluorine to pharmaceuticals to win patent rights might prevent dementia. Fluoride is excreted as aluminium hexafluoride [106], $\quad \mathrm{AlF}_{6}{ }^{=}$; simultaneous brain clearance affords temporary symptomatic relief. The other Alzheimer symptoms, protein tangles, aluminosilicate plaques and cell death are readily understood. A vector for fluorine might prevent or treat dementia.

Infant vitamin D deficiency causes rickets [107], cod liver oil, UV lamps or sunlight can correct it. Fluoridation of water supplies replaces F- with $\mathrm{OH}-$, countering childhood tooth decay by hardening tooth enamel [108]. Tea drinking supplies adequate F-, excessive exposure causes tooth mottling [109].

\section{Assimilation}

Glucose transport mediates carbohydrate metabolism [110], keeping blood, xylem and phloem sugar levels steady [111]. Diabetes results from defective glucose transport, monitoring zinc 


\section{International Journal of Innovative Research in Medical Sciences (IJIRMS) \\ ISSN (Online): 2455-8737, page No. 160 to193 \\ Volume 01, Issue 05, July 2016}

might improve its management. Zn accumulating in diabetics' eyes causes glaucoma [112]. Converting glucose to glycogen, fat and starch [113] in liver, adipose tissue and leaves also regulates carbohydrate metabolism.

Bilirubin released when the higher [O2] associated with breathing air triggers adult haemoglobin replacing the foetal variety [114], causes seizures if it reaches the brain. Colostrum, first breast milk [115], provides the necessary $\mathrm{Zn}$ to add glucose for excretion, preventing neonatal jaundice. Before exposure to blue light was introduced, sucking the midwife's pewter spoon [116] was an effective and less invasive remedy. The silver spoons blue-blooded families substituted were ineffective.

Insulin distributes $\mathrm{Zn}^{++}$from pancreatic $\beta$-cells [117], pancreatic $\alpha$-cells issue glucagon [118], disabling glucose transport and recycling it. Vitamin C derivative 2-keto-Lgulonate [119] delivers it to peripheral tissues insulin can't reach. $\mathrm{Zn}^{++}$primes tDNAs transporting $\beta$ Dglucose, binding specifically to the 'triangle of sweetness'

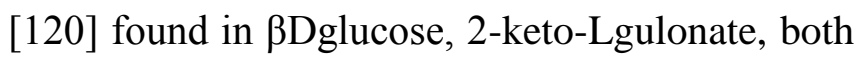
hormones and barbiturates, Fig 3j. Deficient Zn prevents incorporation of hydroxy-proline to connective tissue protein collagen [121], causing scurvy [122] in ancient mariners until the vitamin $\mathrm{C}$ in limes prevented it, prime example of supplementation correcting a deficiency.

Rhinoviruses causing colds and flu enter nasal cells via tDNAs $\mathrm{Zn}$ blocks, accounting for Linus Pauling's promotion of vitamin $\mathrm{C}$ to prevent it [123], the $\mathrm{Zn}$ in a tin of sardines augments it. $\mathrm{Zn}$ regulates our appetites for food and sex, oysters and caviar containing $\mathrm{Zn}$ encourage snacking and increase libido. Eating disorders [124] anorexia nervosa, bulimia and possibly obesity respond to Zn supplements. Excessive alcohol consumption and barbiturates divert $\mathrm{Zn}$ to the liver where $\mathrm{Zn}$ - dependent alcohol dehydrogenase [125] and other enzymes detoxify them. This reduces the brain's $\mathrm{Zn}$ supply, starving it of glucose and causing inebriation. Attention to $\mathrm{Zn}$ might improve the management of alcoholics. Combining barbiturates with alcohol can be lethal [126].

\section{Reproduction}

Beryllium, lead and indium mimic Zn, Victorians called beryllium 'glucinium' for its sweet taste [127], using it as a poison. Romans died from using lead acetate as a sweetener [128]. Indium is diagonally related to $\mathrm{Zn}$ in the periodic table, endocrine glands may exchange it for other divalent trace metal ions for incorporation to hormones. Indium supplements might help control obesity.

The pineal gland [129] assembles 6-member serotonin [130] rings, Fig 4c, round silver ions, $\mathrm{Ag}+$ similar to those catecholamines form around potassium, see Sensitivity. Silver is incorporated to Ag-porphyrin [131]. Iron, magnesium and silver porphyrins have the colours of red blood, green leaves and pink leaf buds. Retinal transfers energy from Ag-porphyrin as solitons for converting phosphate to pyrophosphate. Arginine transports the pyrophosphate.arginine complex, providing the atoms needed for DNA synthesis at cell division [132], Fig 4d. Anti-cancer drugs mimic it.

Silver helps tissue repair and regulates sleep [133]. Before antibiotics displaced them, silver was a common ingredient of medicines [134]. Pharmacists dismiss them as 'quack remedies'. Silver colloid has been proved effective against cancers in animal trials [135], its potential for cancer prevention is uncertain. The roles of phosphate for energy, DNA synthesis and bone and tooth maintenance are managed separately [136], interventions need respect this. 


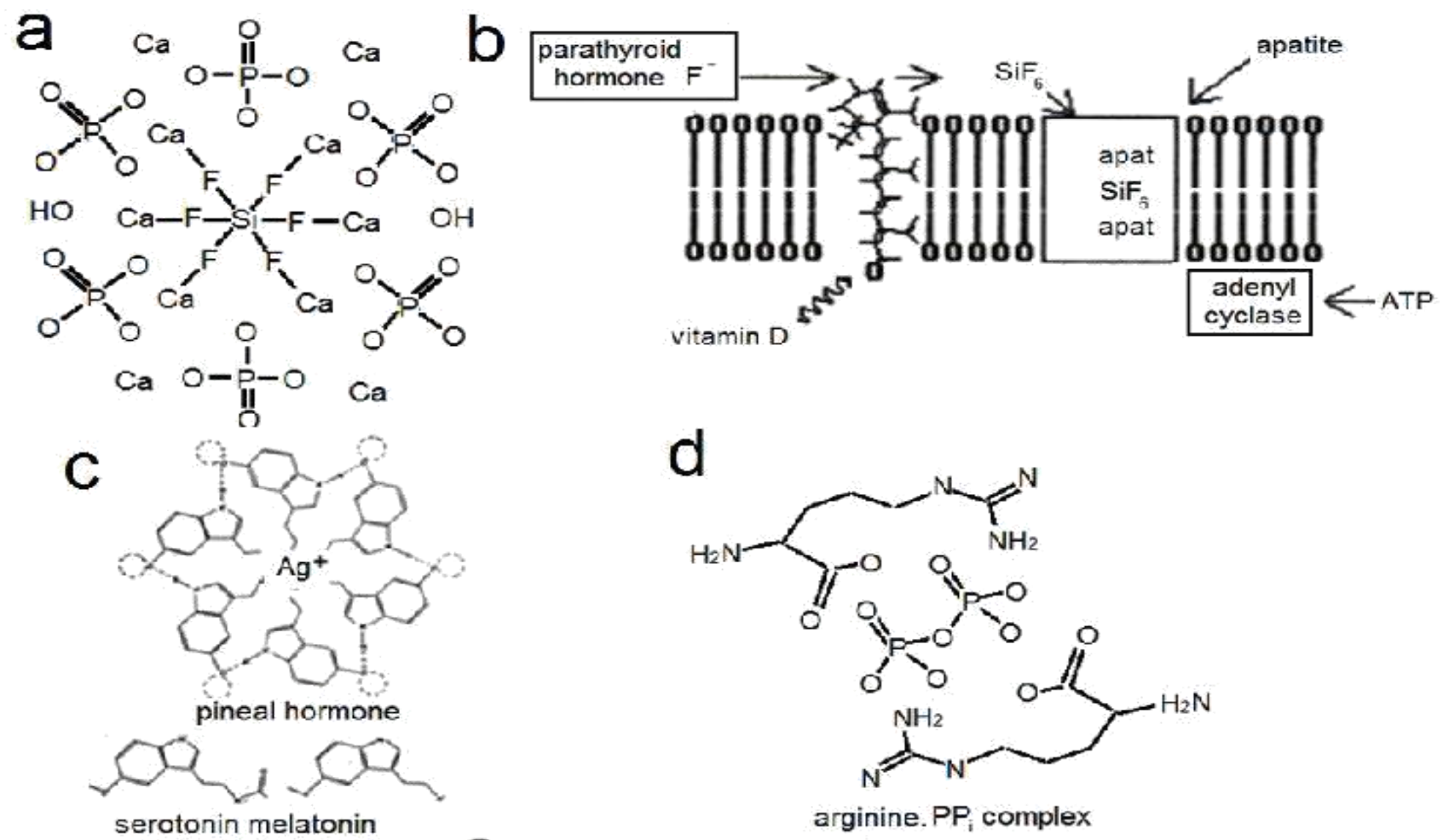<smiles>O=C(O)CC(CCO)(CC(=O)O[Sb](=O)(=O)O)OP(=O)([O-])O</smiles>

phosphomevalonate

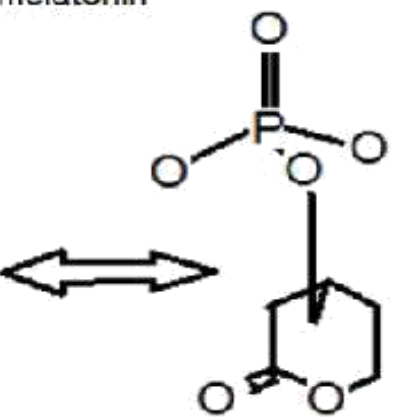

phosphomevalonolactone: f

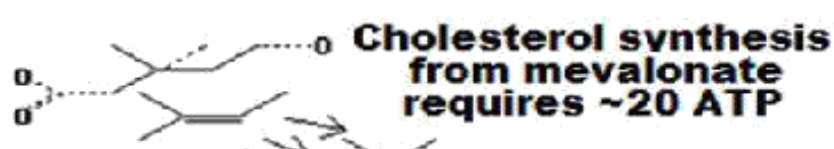

9 (6)<smiles>[131IH]</smiles>
glutathione $\$$ tocopherol<smiles></smiles>

(5)

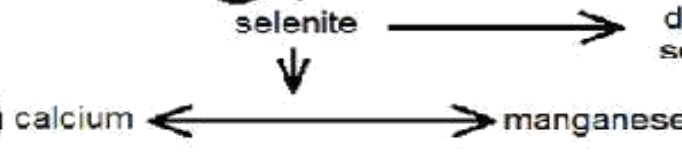

phosphomevalono-lactone + water.

\section{posterior pituitary}

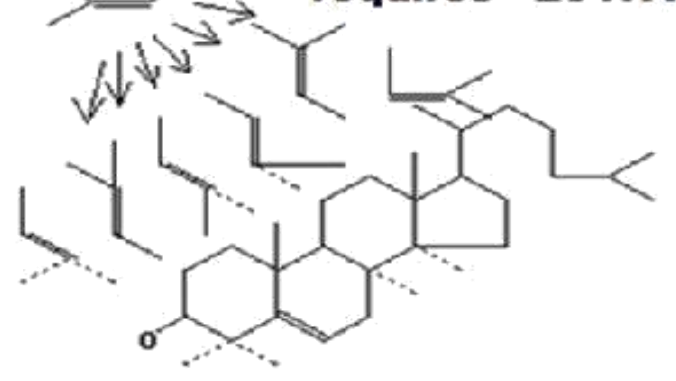

\section{water}

\section{$\uparrow$ BLOOD PRESSURE}

(7) $\mathrm{CONTROL}$

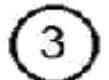

dimethyl. cholesterol
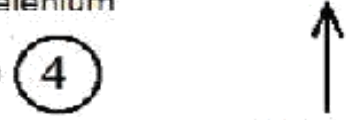

phosphomevalonate
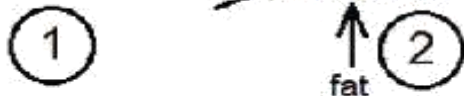

Figure 4. a Silicon hexafluoride-apatite complex, b Silicon hexafluoride synthesis, c Serotonin silver complex, d Pyrophosphate-arginine complex, e Water transport, f Cholesterol synthesis, g Blood pressure controls 


\section{International Journal of Innovative Research in Medical Sciences (IJIRMS) \\ ISSN (Online): 2455-8737, page No. 160 to193 \\ Volume 01, Issue 05, July 2016}

\section{Blood pressure control}

Peter Mitchell's chemiosmotic theory [137] presumes water diffuses freely through unit membranes, describing them as semi-permeable, implying water molecules drift back and forth to equilibrate osmotic pressure differences. If that were true, we'd be safe in salty seawater but absorb bath water through our skin. Exchange of 3 sodium for 2 potassium ions, see Sensitivity, maintains an electric field, the membrane potential [138], making this impossible. Cells must pump water, osmoregulate to survive.

Mevalonate [139], residue of saturated fat breakdown, is named after the herb Valerian, formerly known as 'all heal'. Adding phosphate creates mevalonate-5-phosphate [140], MevP, susceptible to transport by tDNA. MevP reversibly forms mevalonolactone-5-phosphate [141], MevLP releasing a water molecule. Exchanging MevP with MevLP transports water, Fig 4e.

The posterior pituitary gland packs oxytocin and vasopressin [142] with selenium, Se. Vitamin E, $\alpha$-tocopherol delivers energy as solitons, oxidizing $\mathrm{Se}$ to selenite, $\mathrm{SeO} 3=$. Selenite exchanges manganese for calcium. Manganese, $\mathrm{Mn}$ and magnesium, $\mathrm{Mg}$ are both named after the Greek region Magnesia [143]. Remembering the phrase man gains ease reflects the role of manganese in controlling blood pressure. Mn activates enzymes converting surplus mevalonate to cholesterol [144], Fig 4f. Essentially a waste product, this much maligned molecule is feedstock for steroid hormone synthesis.

\section{Blood pressure, Fig $4 \mathrm{~g}$, is controlled by:}

- Inheritance of the tDNA responsible for exchanging MevP for MevLP.

- Saturated fat consumption [145].

- High density lipids are good and low density lipids bad cholesterol transporters [146].
- Mn synthesising cholesterol.

- Exercise and Ca levels.

- Sulphur competing with selenium metabolism.

- Methyl mercury from polluted fish competing with dimethyl selenium for pituitary uptake [147].

- Se and vitamin E deficiencies.

\section{Se deficiency is pandemic, arising from:}

- Precipitation during water purification [148].

- Foods grown in Se-poor soils [149].

- Using high temperatures for food preparation and preservation [150] and

- Eating junk food, European royal families' longevity [151] may be attributed to their rich diets.

It causes pre-eclampsia, hypertension during pregnancy [152], cancers of breast, bowel, cervix and prostate [153], tissues specializing in water pumping and deaths from heart attacks and strokes [154]. Half the deaths of people following a 'Western' life-style arise from poor selenium nutrition. Compare maps of surface geology with those of breast cancer incidence [155]: drinking water coming from igneous rocks, e.g. in Snowdonia, North Wales or young sedimentary rocks, e.g. chalk and limestone around London reduces its incidence. Both originate from remnants of early Se-dependent life fossilised embedded on the seafloor and raised or subducted by plate tectonics. Seafloor manganese nodules [156] may also reflect life's Se-dependency.

Animal husbandry provides the best evidence for Se dependency [157]. The sulphur in superphosphate fertilizers used on sheep pastures competes with Se, causing white muscle disease. Se supplements prevent hypertension during pregnancy in cattle and protect pigs from heart failure en route to market. Limes for scurvy, iodine for goitre, cod liver oil for rickets and 


\section{International Journal of Innovative Research in Medical Sciences (IJIRMS) \\ ISSN (Online): 2455-8737, page No. 160 to193 \\ Volume 01, Issue 05, July 2016}

fluoridation for dental caries are precedents for intervention. Supplementing $\mathrm{Se}$ promises to prevent heart attacks and common cancers, it might prevent or treat Ebola, characterised by water loss [158].

\section{Minion structure}

Minion connotes mind and subservience, minions account for human intelligence better than binary computers modelled on neural networks. They comprise 189 subunits, each with nine uncoiled DNA base-pairs retaining B-helical [159] basepair spacing and overlap held flat by an antiparallel $\beta$-pleated protein sheet [160] with alternate neutral: Ala, Leu, Ile and Val and basic: Arg and Lys residues, Pro forming an asymmetric U-bend, Fig 5a consistent with known nucleohistone amino acid content [161]. Bacterial protein Gramicidin S [162], Fig 5b, has an analogous structure, its Dphenylalanine residues are equivalent to DNA bases. The typical size of siRNAs [163] is consistent with their binding to palindromic DNA sequences two units long. Ala, Leu, Ile and Val bind to bases Cytosine, Guanine, Adenine and Thymine respectively, preserving DNA sequence integrity (mnemonic A LIVe CiGAreTte).

Nine coils formed of 21 subunits with intervening $\sim 17^{\circ}$ bends are bound together by more protein hairpins, Fig 5c. Stacked minions form super-coils consistent with chromosome dimensions, packing DNA on chromosomes, Fig 5e, more neatly than their preparative artefacts, nucleosome core particles [164], Fig 5d. Three types of H-bond are involved in minion architecture: between DNA bases, across $\beta$-pleated sheets and between $\omega$ amines and phosphates, Fig 6c making their intact extraction difficult). They enable 1,701 base pairs to replicate efficiently, Fig 5f, without the copying errors implicit in helicase enzymes [165] unwinding and rewinding the double helix.

\section{Minion function}

Alan Turing [166] asked 'Can machines think ... do well in the imitation game?', artificial intelligence need out-perform binary 'yes' or 'no'. Natural intelligence using logic and analogy has evolved to exceed silicon chip technology. Serving as the chips in our brains, their 18 frequency bands span the same range as a piano with 103-octaves and the knowable electromagnetic spectrum. Unlike the neural network brain model [167], they embrace neurological, psychiatric and philosophical personality traits. Sensory cells encode information on minions for recognition throughout the brain.

The H-bonds connecting Arg or Lys $\omega$-amines to DNA phosphate on each coil surface oscillate like rows of dominoes collapsing, Fig 6a, accelerating protons along minions' 18 tunnels, $\mathbf{T}$ in Fig 6c. One is reversed for electrical neutrality. The $9 * 63$ proton ordered arrays on their inner and outer surfaces store information as 18-letter words using a 63 character alphabet. The $1.8 \mathrm{M}$ minions in any human cell nucleus could store the Bible, Koran and Shakespeare's works.

Each constitutes one of the 18 hands of a biological clock with time unit, $\tau$ that light takes to travel thrice round the fastest coil:

$$
\begin{gathered}
=3 * 189 * 7.37 * 10^{-10} * 3 * 10^{8} \approx 1.39 * 10^{-15} \\
\text { seconds },
\end{gathered}
$$

where 3 reflects Dekatron ${ }^{\mathrm{TM}}$ [168], logic (c.f. Geiger counters), 189 the number of base pairs per coil, $7.37 \AA$ is $\beta$-sheet spacing and $3 * 10^{8}$ the velocity of light. Using $63^{\mathrm{N}} \tau, \mathrm{N}=1$ to 18 , coils 11, 13 and 18 have periods approximating day length, Sun spot cycle period [169] and the age of the universe [170]. Times outside the range $\tau$ to $63^{18} \tau$ and mathematical 0 and $\infty$ are unknowable. The minion's handedness, chirality, determines the direction of time. 

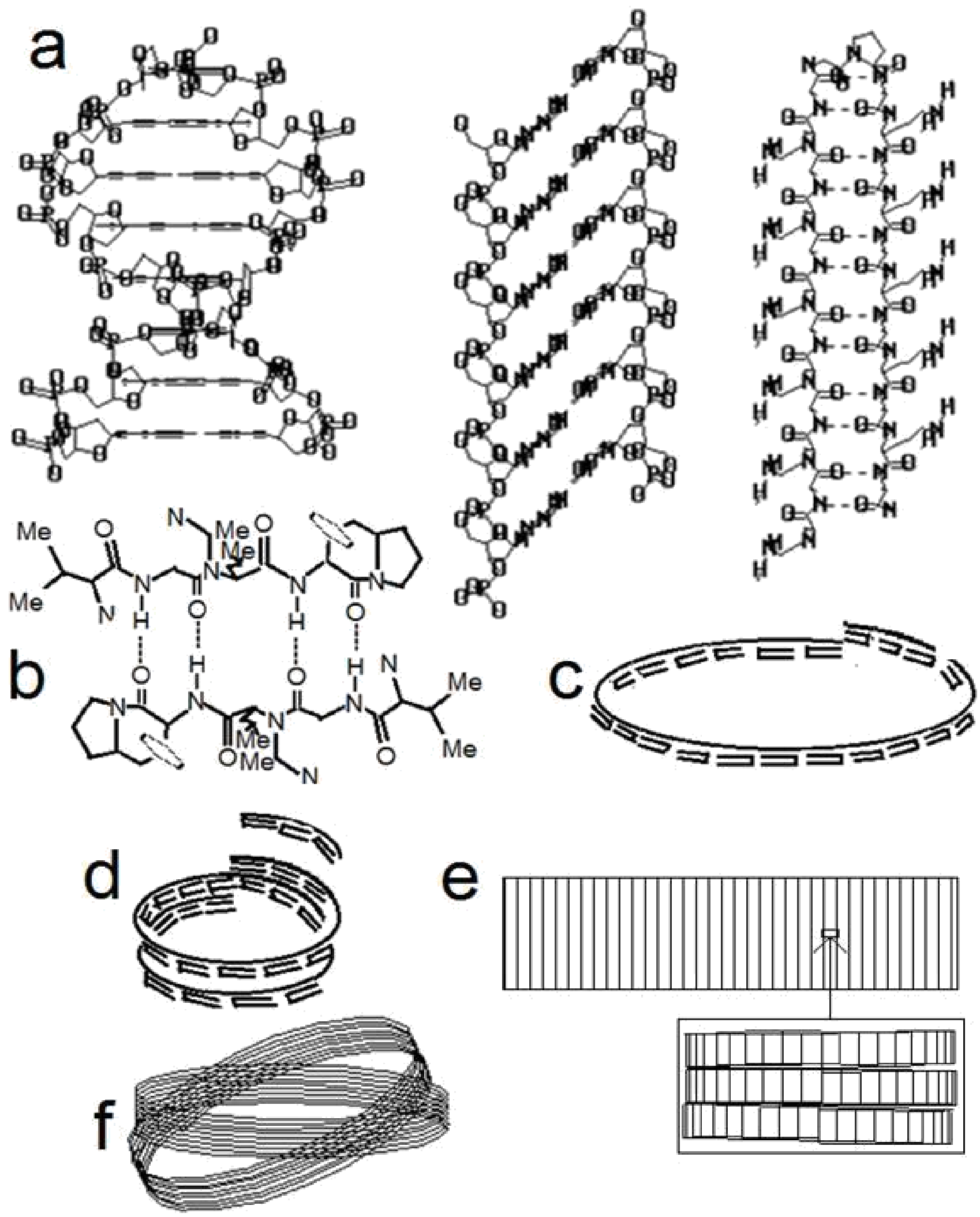

Figure 5. a B-helix uncoils retaining base pair spacing and overlap and binds to anti-parallel $\beta$-pleated sheet, b Gramicidin S, c 21 9-base pair units per coil, d Nucleosome core particle, e Stacked minions fit chromosome, $f$ Minions replicate 1,701 base pairs. 

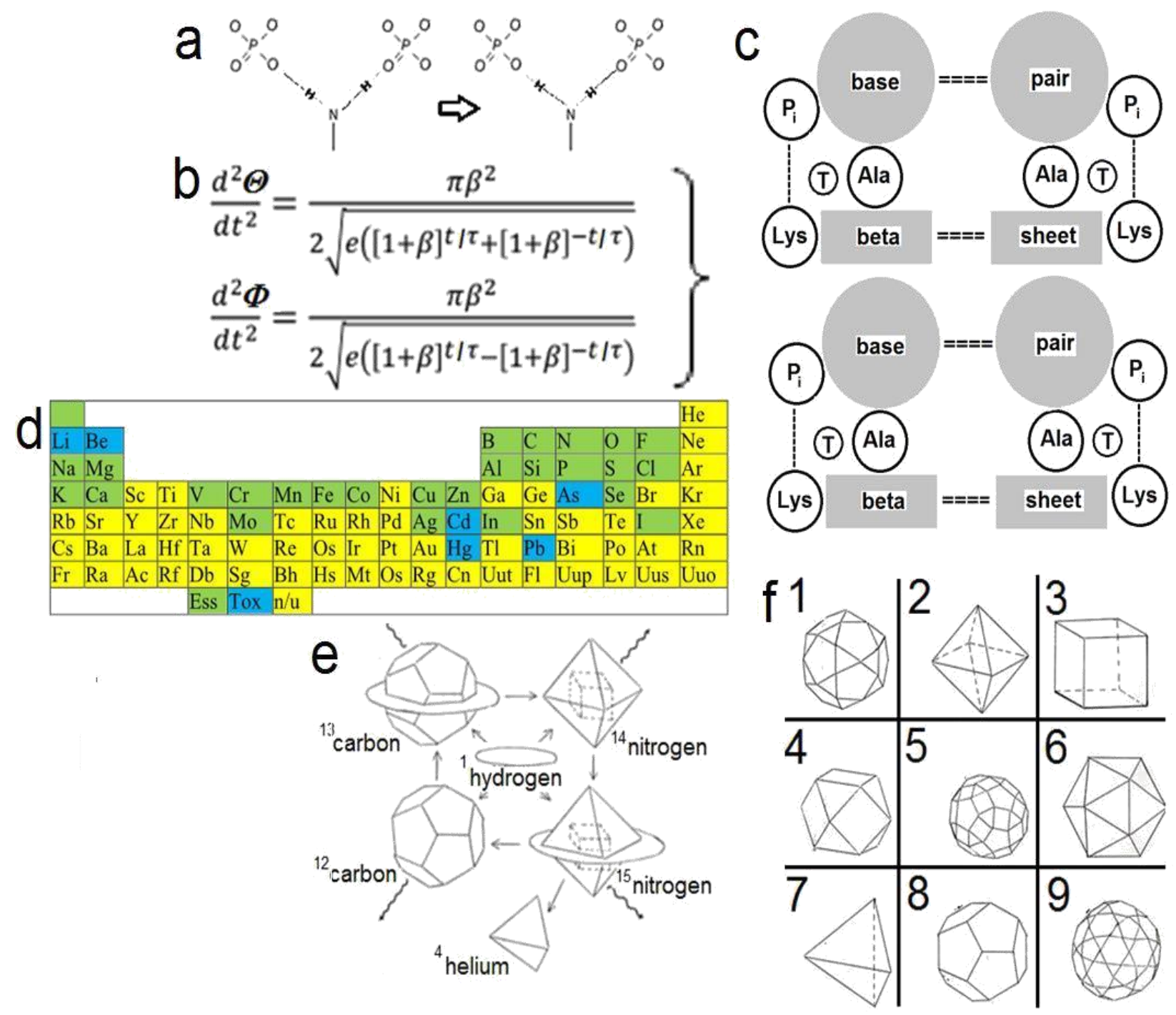

Figure 6. a Oscillating H-bonds, b Tyger equation in polar coordinates $\theta$ and $\varphi$, where $\beta=63^{-9}, \tau \approx 1.4$ femtoseconds, $\pi$ and e have their standard values, $c$ End view of stacked minions showing three sets of H-bonds and tunnels, T, d Periodic table showing essential and toxic elements, e Carbon nitrogen cycle, f Nine 'perfect solids'.

Minions play unique chords corresponding to the words they store, resonating with minions storing similar words within the same nucleus or others connected by nerve fibres and accounting for memory recall, partial matches suggest compromise. Recognition is analogous to ringing a bell and music appreciation. Nerve fibres are equivalent to optic cables, serving as wave-guides [171], the synaptic junctions act as filters. Differentiated brain regions use different tDNAs and chemistry. Minions practice reading, writing and arithmetic, counting from 1 to $63^{18} \sim 2.444 *$ $10^{32}$ like coiled abaci with 63 beads on 18 rungs, consistent with using ratios, percentages, exponents and logarithms [172] when making comparisons.

Minions compare ideas from all branches of knowledge, Tables 3 to 6 , treating their practitioners with compassion and respecting their intelligence. Human intellect translates experience into words, pictures and symphonies; lateral thinking is equivalent to changing key in music or synaesthetes [173] (attributing colours to letters and numbers) transposing meanings between senses. It's achieved by transposing thoughts 


\section{International Journal of Innovative Research in Medical Sciences (IJIRMS) \\ ISSN (Online): 2455-8737, page No. 160 to193 \\ Volume 01, Issue 05, July 2016}

between minion coils. When gamblers confuse cardinal and ordinal numbers [174], they substitute emotion for logic.

Indexing information according to the minion's 18 categories would improve search and retrieval, it's consistent with the 26 letters in the alphabet, counting using base 10 arithmetic and the 64 entries in

the I Ching [175], embracing all neurological, psychiatric and philosophical personality types. Languages give equal weight to past, present and future, confirming time may be an illusion [176]. The realization of prophecy arises from human nature. The minion's vocabulary is finite, including right, wrong, kindness, hatred, wisdom and idiocy, each word has a colour and meaning. C.f. Shakespeare's Merchant of Venice featuring gold, bronze and silver caskets corresponding to truth, love and justice. Political parties and national flags use particular colours and they feature in common metaphors. Imagination is unlimited, high resolution photographs and clay models can substitute for paintings and sculptures.

Integrating the personality classifications used by neurologists, psychiatrists and philosophers [177], identified nine independent (mathematically orthogonal) personality traits: goodness, truth, beauty, peace, love, progress, stability, justice and unity, subject to semantic interpretation. They correspond to nine 'senses': instinct, belief, aesthetics, joy, touch, hearing, taste, vision and smell. The deaf, blind, sensory deprived and synaesthetes substitute one for another. The personalities of academics following different disciplines reflect time periods, colours and masses typical of their interests. Negative and positive traits determine judgment and behaviour respectively, corresponding to introversion and extroversion [178].

The consensus model treats brains as digital computers with data distributed in a network. If information was localized, brain damage would destroy memories, contrary to experience - in old age, most people remember their childhood. Minion memories resemble holographs [179]. Minion logic embraces all beauty, genius and wisdom; proposals arising from it challenge consensus opinions and make verified predictions. Like silicon chips, minions are clocks, memory stores and communicate reflecting their owner's personality. Biological clocks share a common origin, they're all in phase, [O2] changing at birth legitimizes astrology [180], Tables 4 and 5. Interminion signals are confined to the brain, ensuring privacy. Synchrony between minions accounts for telepathy [181].

$\tau$ is the anthropological equivalent of Planck's constant, h [182]. Tests of Heisenberg's uncertainty [183], Einstein's relativity [184] and le Maitre's big bang cosmology [185] using particle accelerators, telescopes and satellites are prone to error. The Tyger equation, Fig $6 \mathrm{~b}$, is a hyperbolic function [186] inspired by Blake's 'What immortal hand or eye dare frame thy fearful symmetry?' [187] creating relativity between perception and conception and making 1 in $10^{15}$ wrap-around counting errors resolving these discrepancies. Minions distort our perception of a light beam's path, accounting for Einstein's 'spooky action at a distance' [188]. Earth's curvature and gravitation and creating the counter-intuitive illusion that fundamental particles, Earth's surface and stars are plane surfaces. An expert in topography might confirm its consistency with the mutual eclipsing of moons and planets.

The energy of protons accelerated along minion tunnels is:

$$
1 / 2 \mathrm{pm}(\mathrm{c} / 189)^{2} \approx 13,000 \mathrm{eV}
$$

Where $\mathrm{pm}=$ proton mass, $1.67 * 10^{-27} \mathrm{~kg}$, sufficient to fuse with the atomic nuclei of molecular obstructions. They serve as molecular- 


\section{International Journal of Innovative Research in Medical Sciences (IJIRMS) \\ ISSN (Online): 2455-8737, page No. 160 to193 \\ Volume 01, Issue 05, July 2016}

scale cold fusion reactors, equivalent to the $\mathrm{H}-$ bond-lined tracks under water adhering to palladium crystals Fleischmann and Pons investigated [189].

The human race carries $\sim 10^{28}$ minions, $\sim 30 \mathrm{Mt}$ of chromatin, sufficient to replenish life's atomic constituents, $\mathrm{H}, \mathrm{C}, \mathrm{N}, \mathrm{O}, \mathrm{S}$ and $\mathrm{P}$. Nested polyhedral shells of planes, reminiscent of Plato's perfect solids [190], Fig 6f, replace orbiting electrons and single, double, triple and $\mathrm{H}$-bonds
$(-,=, \equiv$ and $\cdots \cdot)$ reinterpret Mendeleev's periodic table of the elements [191] Fig 6d and Table 2, affording new chemical and biochemical insights and the carbon-nitrogen cycle [192], Fig 6e: proton planes fuse with ${ }^{12} \mathrm{C} \rightarrow{ }^{13} \mathrm{C} \rightarrow{ }^{14} \mathrm{~N} \rightarrow{ }^{15} \mathrm{~N}$ $\rightarrow{ }^{4} \mathrm{He}+{ }^{12} \mathrm{C}$, releasing $\gamma$-rays. The ${ }^{1 / 2}$-lives and energies of recoiling nuclei correlate with those of pulsars [193], DNA diffracts the $\gamma$-rays released at source and they return like boomerangs according to the Tyger equation.

Table 2. Periodic table, essential, toxic and unused elements

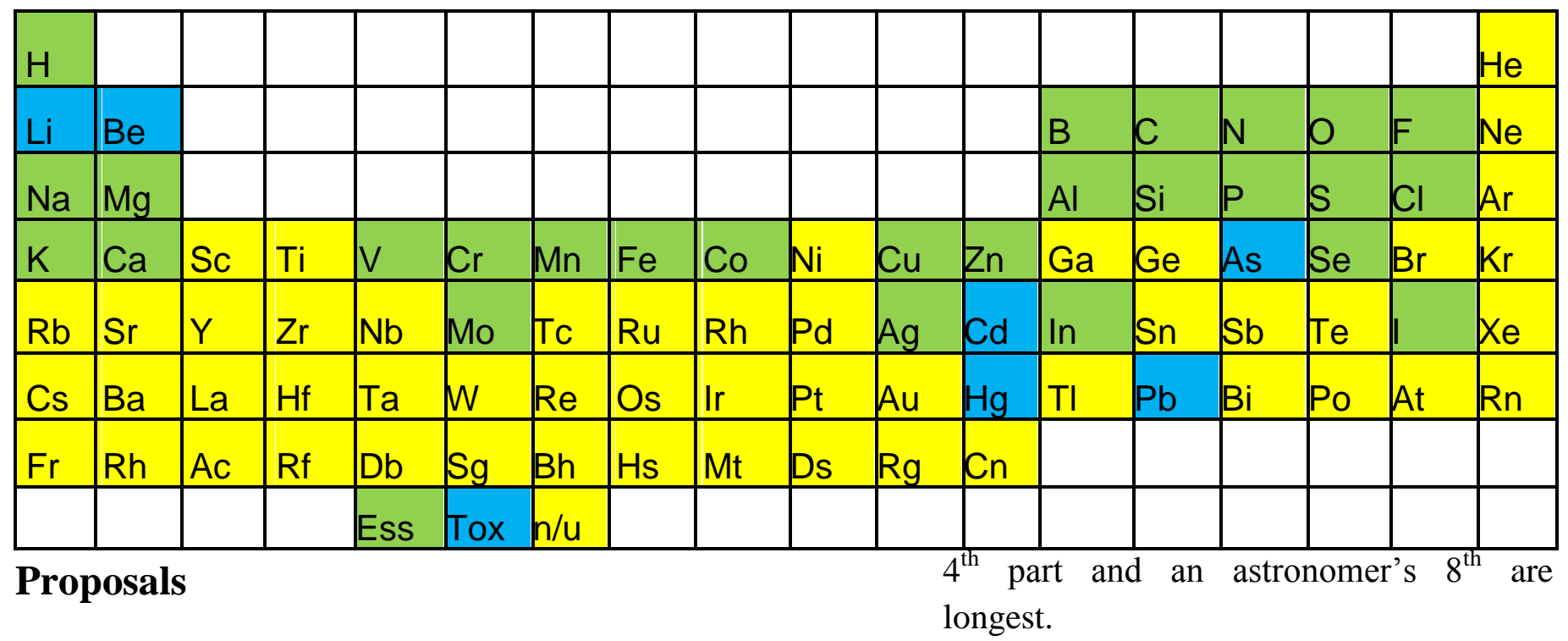

There are many ways to understand coil characteristics:

- Reading William Shakespeare's Seven ages of man [194], Table 3, Chaucer's Canterbury tales [195] and astrology texts [196], Table 4.

- Visiting art galleries, libraries and museums and noting how the personalities of artists, writers and inventors determine their masterpieces' qualities and the 7-year period it was produced in.

- Lectures, theses and publications may be split into nine parts. Their lengths reflect the author's personality. E.g. a technical specification's $2^{\text {nd }}$ part, a political essay's
- Ages of puberty at 14 , majority at 21 and retirement at 63 are widely respected.

- Qualities associated with zodiac signs are consistent with base-9 minion logic.

- Astrological Great Ages 2000 years long, Table 5, provide a framework for understanding history.

- Plato advocated goodness, truth and beauty; the Age of Aquarius promises peace, love and progress and political parties preach stability, justice and unity, Table 6. 


\section{International Journal of Innovative Research in Medical Sciences (IJIRMS) \\ ISSN (Online): 2455-8737, page No. 160 to193 \\ Volume 01, Issue 05, July 2016}

Table 3. Seven year periods

\begin{tabular}{|c|l|l|l|}
\hline$\#$ & METAPHOR & SENSE & \multicolumn{1}{c|}{ 7-YEAR PERIOD } \\
\hline 1 & greenhorn & instinct & $0-7$ infants are good, 63-72 retirees enter $2^{\text {nd }}$ childhood \\
\hline 2 & golden truth & belief & 7-14 children learn truth, 72-81 oldies resume education \\
\hline 3 & pied beauty & aesthetics & $14-21$ teens enjoy beauty, $81-88$ pensioners are content \\
\hline 4 & daffodils & joy & $21-28$ adults respect ethics, $88-91$ elders impart wisdom \\
\hline 5 & roses & touch & $28-35$ parents conform, dotage, 91-98 revives memories \\
\hline 6 & crocuses & hearing & $35-42$ workers advance their careers \\
\hline 7 & conservative & taste & $42-49$ in middle age, they invest savings \\
\hline 8 & liberal & sight & $49-56$ citizens advise and publish \\
\hline 9 & socialist & smell & 56-63 leaders govern \\
\hline
\end{tabular}

Table 4. Qualities associated with astrological zodiac signs

\begin{tabular}{|l|l|l|l|l|l|}
\hline$\#$ & QUALITY & ZODIAC SIGN & $\#$ & QUALITY & ZODIAC SIGN \\
\hline-1 & goodness & Cancer & +1 & goodness & Aries \\
\hline-2 & truth & Scorpio & +2 & truth & Leo \\
\hline-3 & beauty & Pisces & +3 & beauty & Sagittarius \\
\hline-4 & peace & $*$ & +4 & peace & Gemini \\
\hline-5 & love & $*$ & +5 & love & Libra \\
\hline-6 & progress & $*$ & +6 & progress & Aquarius \\
\hline-7 & stability & Taurus & +7 & stability & $*$ \\
\hline-8 & justice & Virgo & +8 & justice & $*$ \\
\hline-9 & unity & Capricorn & +9 & unity & $*$ \\
\hline
\end{tabular}

\section{Table 5. Astrological great ages}

The Roman Empire ended the Age of Aries, emphasizing stability, justice and unity. Emperors used bronze ornaments and wore purple togas, Buddhists wear saffron robes.

\begin{tabular}{|l|l|l|l|l|l|}
\hline Cancer & -goodness & Scorpio & -truth & Pisces & -beauty \\
\hline Gemini & +peace & Libra & +love & Aquarius & +progress \\
\hline Taurus & -stability & Virgo & -justice & Capricorn & -unity \\
\hline Aries & +stability & Leo & +justice & Sagittarius & +unity \\
\hline
\end{tabular}

The Age of Pisces, $\sim 0-2000$ AD, peaked in the Renaissance and Victorian Empire, emphasizing goodness, truth and beauty. Imperial flags tended to be red, silver and blue.

\begin{tabular}{|l|l|l|l|l|l}
\hline Cancer & -goodness & Scorpio & -truth & Pisces & -beauty \\
\hline Gemini & +peace & Libra & +love & Aquarius & +progress \\
\hline Taurus & -stability & Virgo & -justice & Capricorn & -unity \\
\hline Aries & +goodness & Leo & +truth & Sagittarius & +beauty \\
\hline
\end{tabular}

The Age of Aquarius, emphasizing peace, love and progress, started 2000 AD. Newly independent nations have often chosen green, gold and yellow flags.

\begin{tabular}{|l|l|l|l|l|l|}
\hline Cancer & -peace & Scorpio & -love & Pisces & -progress \\
\hline Gemini & +peace & Libra & +love & Aquarius & +progress \\
\hline Taurus & -stability & Virgo & -justice & Capricorn & -unity \\
\hline Aries & +goodness & Leo & +truth & Sagittarius & +beauty \\
\hline
\end{tabular}




\section{International Journal of Innovative Research in Medical Sciences (IJIRMS) \\ ISSN (Online): 2455-8737, page No. 160 to193 \\ Volume 01, Issue 05, July 2016}

Table 6. Qualities associated with minion coils

\begin{tabular}{|l|l|l|l|l|l|}
\hline$\#$ & QUALITY & PERIOD & COLOUR & MASS & DISCIPLINE \\
\hline-9 & unity & $8.7 \mathrm{fs}$ & Red & $\mathrm{me} / 7$ & quantum mechanics \\
\hline-8 & justice & $5.5 \mathrm{ps}$ & Silver & $\mathrm{m} / 7$ & physics \\
\hline-7 & stability & $350 \mathrm{ps}$ & Blue & $2 *$ base pair mass & chemistry \\
\hline-6 & progress & $22 \mathrm{~ns}$ & Violet & $8.3 \mathrm{ng}$ & computer processing \\
\hline-5 & love & $1.4 \mu \mathrm{s}$ & Bronze & $0.033 \mathrm{pg}$ & biochemistry \\
\hline-4 & peace & $87 \mu \mathrm{s}$ & Yellow & $130 \mathrm{pg}$ & genetics \\
\hline-3 & beauty & $5.5 \mathrm{~ms}$ & Pied & $0.51 \mu \mathrm{g}$ & biology \\
\hline-2 & truth & $350 \mathrm{~ms}$ & Gold & $2 \mathrm{mg}$ & engineering \\
\hline-1 & goodness & $22 \mathrm{~s}$ & Green & $8.1 \mathrm{~g}$ & psychology \\
\hline+1 & goodness & $23 \mathrm{~min}$ & Green & $32 \mathrm{~kg}$ & psychiatry \\
\hline+2 & truth & $1 \mathrm{day} *$ & Gold & $130 \mathrm{t}$ & head hunting \\
\hline+3 & beauty & $9 \mathrm{weeks}$ & Pied & $0.5 \mathrm{Mt}$ & sociology \\
\hline+4 & peace & $11 *$ & Yellow & $2,000 \mathrm{Mt}$ & politics \\
\hline+5 & love & $685 \mathrm{y}$ & Bronze & $8 \mathrm{Gt}$ & history \\
\hline+6 & progress & $43 \mathrm{ky}$ & Violet & $31 \mathrm{Pt}$ & archaeology \\
\hline+7 & stability & $2.7 \mathrm{My}$ & Blue & $1.8 * \mathrm{moon}$ mass & palaeontology \\
\hline+8 & justice & $170 \mathrm{My}$ & Silver & $84 *$ Earth mass & astronomy \\
\hline+9 & unity & $11 \mathrm{By} *$ & Red & $1 * \mathrm{Sun} \mathrm{mass}$ & cosmology \\
\hline
\end{tabular}

Where the numbers label inner and outer coil surfaces; periods $=63^{\mathrm{N}} \tau$, their units $\mathrm{f}=10^{-15}, \mathrm{p}=$ $10^{-12}, \mathrm{n}=10^{-9}, \mu=10^{-6}, \mathrm{~m}=10^{-3}, \mathrm{M}=10^{6}, \mathrm{~B}=$ $10^{9}, \mathrm{G}=10^{12}$ and $\mathrm{P}=10^{15}$; colours feature in metaphors, advertisements, national flags and political logos; ratio between masses $=63^{2}$, me $=$ electron mass,

$\mathrm{mp}=$ proton mass (ants carry many times their weight, elephants can't, suggesting the square root of mass, $\mu=\sqrt{\mathrm{M}}$ is more appropriate for measuring weight, making Einstein's $\mathrm{E}=\mathrm{Mc}^{2}$ more symmetric: $E=\mu^{2} c^{2}$ ).

Counting using our fingers and toes isn't the only way. Since the results of calculations are independent of the base of arithmetic used, proving that minions use bases 9 and 63 isn't easy. Background evidence includes:
- Gray's Anatomy [197] used 9 colours for brain regions.

- The octaves and ratios between notes of the tonic scale [198] are consonant with minion structure.

- Chinese tonal pronunciation [199], perfect pitch recognition and the musical stave's 5 lines and 4 spaces.

- Base-3 in theology: three in one, body mind and spirit.

- Base-7 determines the days in a week

- Base-9 underpins fadic addition invoked in numerology [200].

- Base-10 served the Babylonians, Greeks and Romans, Napoleon proposed a base10 calendar [201]. 


\section{International Journal of Innovative Research in Medical Sciences (IJIRMS) \\ ISSN (Online): 2455-8737, page No. 160 to193 \\ Volume 01, Issue 05, July 2016}

- Base-11 is popular with string theorists [202], unconsciously allowing their minions to override logic.

- Base-12 features in the calendar's solar months and imperial measures.

- Base-60 for time keeping and triangulation.

\section{Investigations could cover:}

- The symmetries of pyramids and other religious monuments and the cost of their construction

- Karl Marks' assertion 'Religion is the opium of the people' [203], doesn't preclude religious tolerance, free speech and human rights.

- Astrological predictions are imprecise but warn of recurrent cyclic events.

- Horoscopes offer valuable clues for medical diagnosis, genetic and environmental determinants of health problems are partial.

- Minions offer a basis for understanding human intelligence.

A philosophical analysis could establish that the nature of reality depends on the observer and all life forms share the same atomic alphabet, molecular vocabulary and metabolic grammar. Scientists could verify my accounts of: the origin of life, re-focussing attention on energy rather than carbon chemistry; the importance of trace element nutrition and minion structure and logic using available techniques. Engineers could model computer systems on minions, creating AI compensating for astrological, psychological and philosophical personality biases and facilitating peace negotiations, designing educational curricula, making management decisions and encouraging green field $R \& D$ on novel ideas. Skills, traditions and beliefs can be enhanced, debated and changed through education, affording every citizen a part in society.

\section{Conclusion}

The Greeks argued that matter consists of indivisible particles, Newton referred to corpuscles of light and quantum mechanics invokes a menagerie of fundamental entities. Allowing for the relativity between perception and conception is only necessary in such esoteric disciplines as particle physics and cosmology. Establishing interdisciplinary collaborations liaising with publicists, scientific principles could enhance Earth life's future. If the following list of references is insufficient, first consult Wikipedia or ask someone you know. Emails to the author will be answered as soon as possible.

\section{Five conjectures}

1. William Blake's 'What immortal hand or eye dare frame thy fearful symmetry?' gave the Tyger equation, Fig. 7, its name. It describes how minions perceive straight lines using polar coordinates $\Theta$ and $\Phi, \beta=$ $63^{-9}, \tau \approx 1.39 * 10^{-15} \mathrm{sec}$ and $\mathrm{e}=$ base of natural logarithms.

$$
\left.\begin{array}{l}
\frac{d^{2} \Theta}{d t^{2}}=\frac{\pi \beta^{2}}{2 \sqrt{e\left([1+\beta]^{t / \tau}+[1+\beta]^{-t / \tau}\right)}} \\
\frac{d^{2} \Phi}{d t^{2}}=\frac{\pi \beta^{2}}{2 \sqrt{e\left([1+\beta]^{t / \tau}-[1+\beta]^{-t / \tau}\right)}}
\end{array}\right\}
$$

Figure 7. The Tyger equation

A topological argument might prove light warped in this way makes plane surfaces appear spherical, implying everything from fundamental particles to stars consists of planes.

2. My account of Heisenberg's uncertainty principle is based on $\tau$, the minion biological clock's time unit, replacing Planck's constant, h. It's that taken for the H-bonds between DNA phosphates and 
amino acid $\omega$-amines to switch like rows of dominoes collapsing. The minion's 18 tracks constitute the clock's 18 hands, using $\beta$-sheet spacing $7.37 \AA$ and the velocity of light, the time to travel thrice round the fastest coil is: $\tau=3 * 189 * 7.37$ $* 10^{-10} / 3 * 10^{8} \approx 1.39 * 10^{-15}$ sec. the ' 3 ' reflects Dekatron ${ }^{\mathrm{TM}}$ logic and there are 189 base pairs per coil. Coils 1 to 18 take $63^{\mathrm{N}} * \tau$, the $11^{\text {th }}, 13^{\text {th }}$ and $18^{\text {th }}$ yield daylength, Sun-spot cycle period and the age of the universe respectively. Time intervals outside the range $\tau$ to $63^{18} * \tau, 0$ and $\infty$ are unknowable. My logic needs review.

3. The minion's oscillating H-bonds accelerate protons, mass pm, along adjacent tunnels, $\mathrm{T}$ with sufficient energy to fuse with atomic nuclei obstructing their passage: $1 / 2 \mathrm{pm}(\mathrm{c} / 189)^{2} \approx 13,000 \mathrm{eV}$

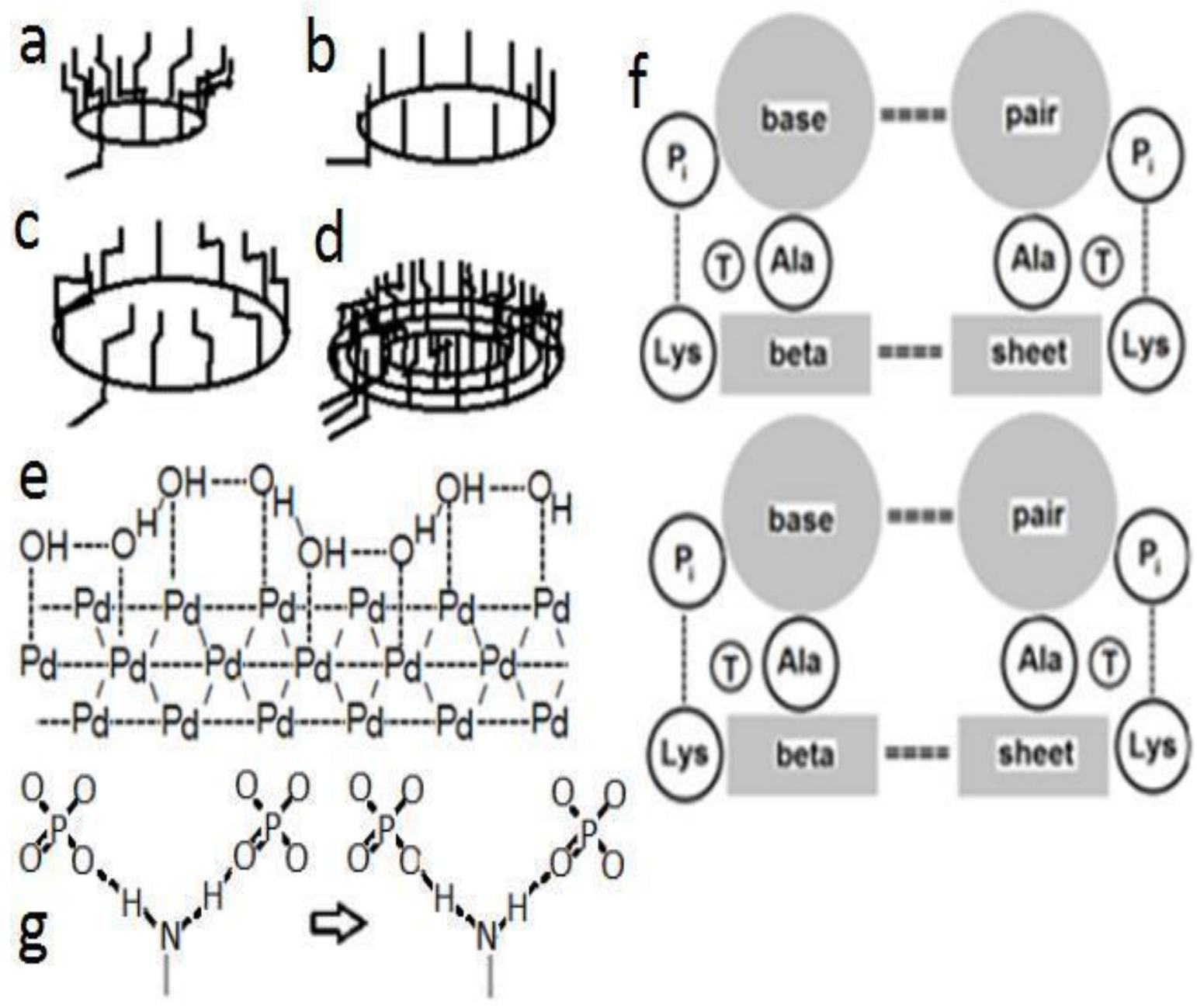

Figure 8. a, b, c, d Dekatron ${ }^{\mathrm{TM}}$ assembly, e H-bond switching in Pd-bound $\mathrm{H}_{2} \mathrm{O}$, $\mathrm{f}$ Tunnels along minion coils, g Phosphate-amine H-bond switch

According to my $1^{\text {st }}$ conjecture, the carbonnitrogen cycle can be represented using nuclei formed of plane combinations. Inserting four plane protons, the $1^{\text {st }}$ to dodecahedral ${ }^{12} \mathrm{C} \square{ }^{13} \mathrm{C}$, $2^{\text {nd }} \square$ octrahedron and cube ${ }^{14} \mathrm{~N}, 3^{\text {rd }} \square$ unstable ${ }^{15} \mathrm{~N}$ and $4^{\text {th }}$ releases tetrahedral ${ }^{4} \mathrm{He}$, leaving ${ }^{12} \mathrm{C}$. 

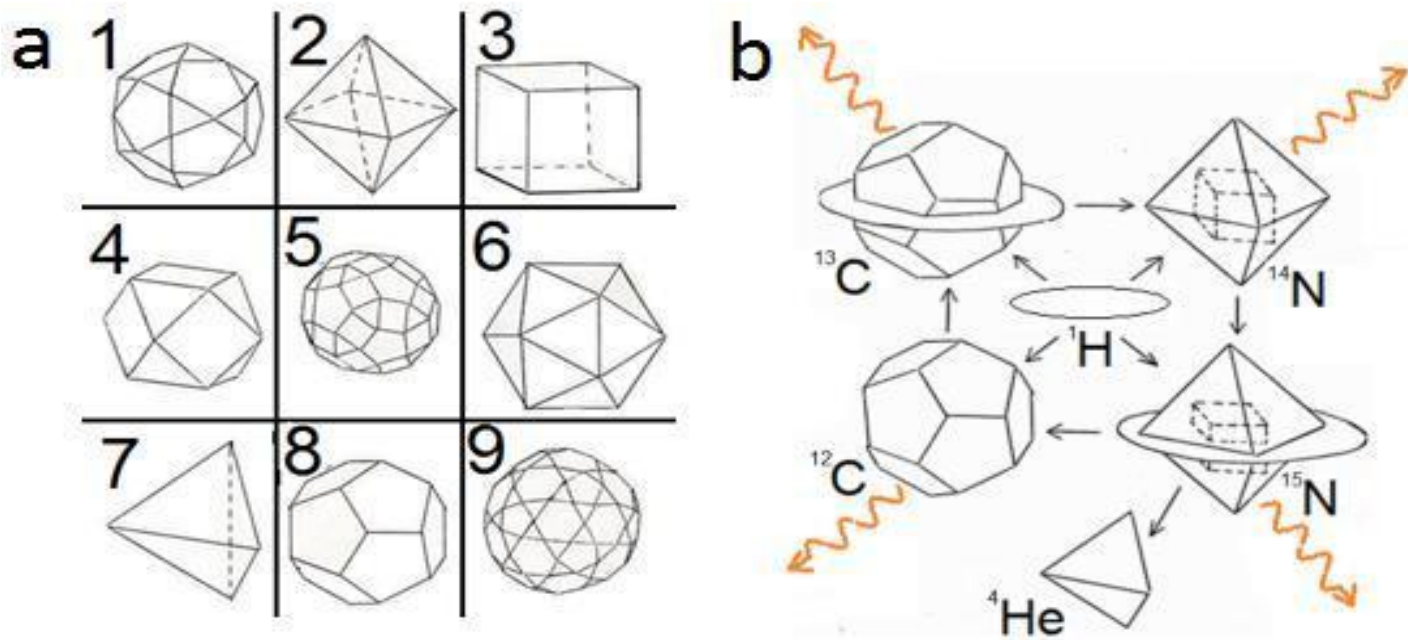

Figure 9. a Nine plane combinations, b carbon-nitrogen cycle

The reaction products, e.g. from collisions with ${ }^{12} \mathrm{CO}_{2}\left|{ }^{13} \mathrm{CO}_{2},{ }^{14} \mathrm{NO}_{2}\right|{ }^{15} \mathrm{NO}_{2},{ }^{12} \mathrm{CH}_{4} \mid$ ${ }^{13} \mathrm{CH}_{4}$ and ${ }^{14} \mathrm{NH}_{4} \mid{ }^{15} \mathrm{NH}_{4}$ emit $\gamma$-rays. The correlation between their $1 / 2$-lives and energies with those of pulsars calls for statistical verification. Implicitly, lifegenerated $\gamma$-rays are diffracted by biological moieties and warped by the Tyger equation, returning to source like boomerangs. The cold fusion Fleischmann and Pons reported on palladium, neutron emission during electric storms and c avitation when bubbles collapse have similar explanations.

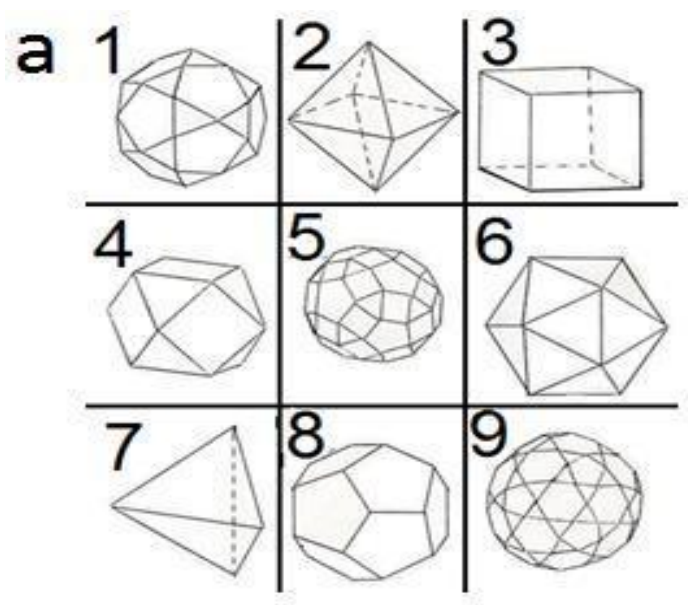

4. 'Differentiation DNA' bound 'transport DNA's encode 'hook' proteins determining tissue architecture. Eggs, sperm and immune system white blood cells have 1 hook, filamentous algae like spirogyra have 2 , sponges are sheets of cells connected by 3 hooks, primitive worms consist of bi-layers joined by 4 hooks and our essential organs use 5 hooks. 6 hooks allow unlimited growth of tumours and cancers unless the immune system prevails. The 6 hook theorem, a 3dimensional version of the four colour mapping theorem, needs proof.

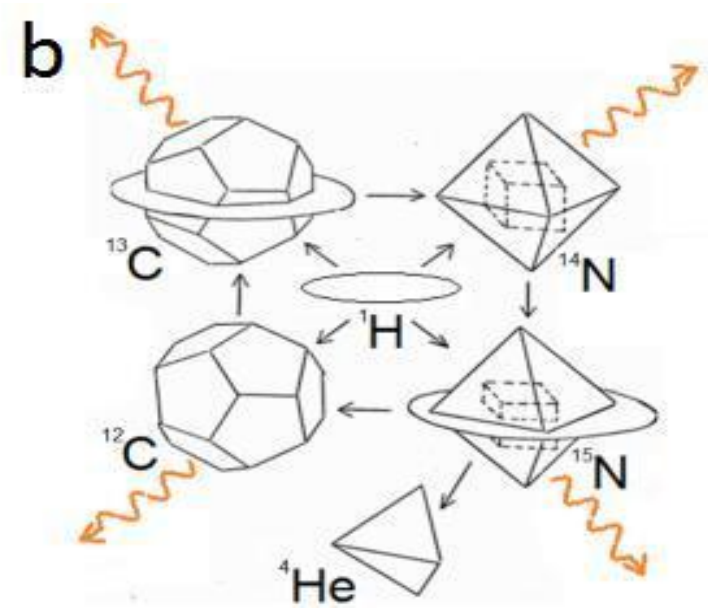

Figure 10. Five cell combinations, 6th allows tumour/cancer formation 
5. My serendipitous discovery of a tetragonal variant of cubic ice crystallizing in liquid nitrogen was recently corroborated. 16 ice structures are now known, some orderly, most existing only at extreme temperatures and pressures. Ice XIc has a diamond-like structure. At $72 \mathrm{~K}$ it undergoes a ferroelectric phase transition to accommodate water molecules' irregular tetrahedral shape, sharing the entropy Linus Pauling established for ice Ih above that temperature: $\mathrm{O} \bullet \bullet \mathrm{H}-\mathrm{O}$ or $\mathrm{O}-\mathrm{H} \bullet \bullet \mathrm{O}$ at random.

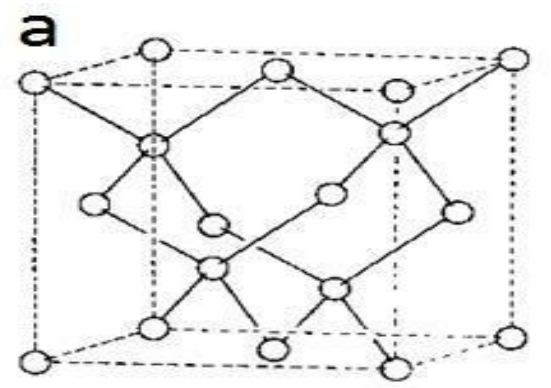

C

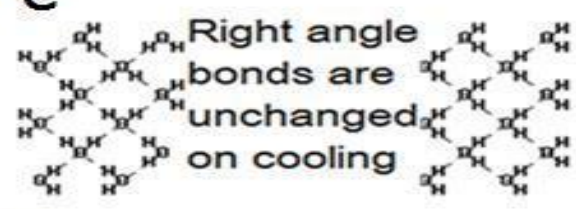

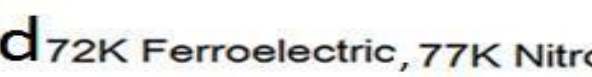
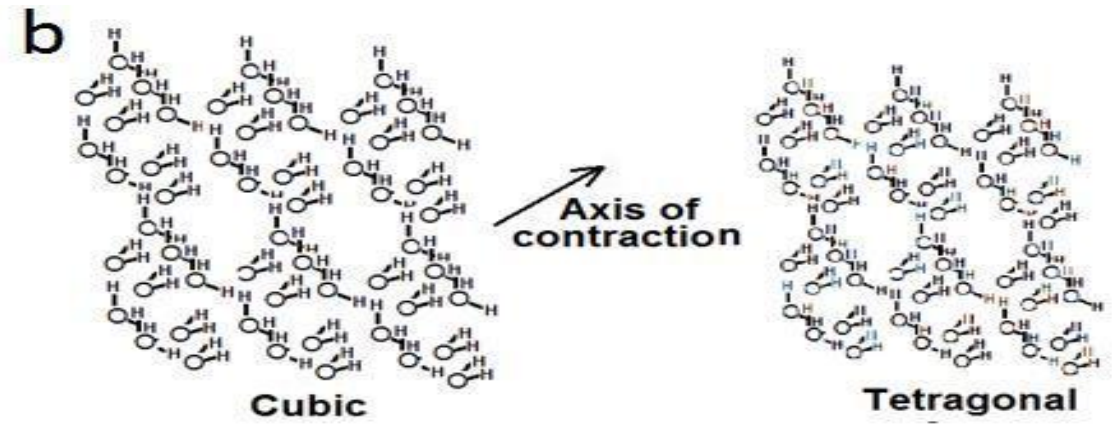

Random

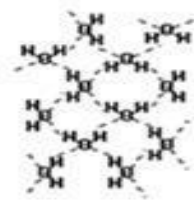

angles

retain disorder

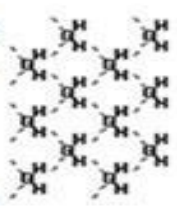

Transition accommodates bond angles

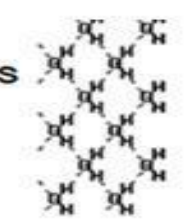

Figure 11. a Diamond structure, b Ferroelectric transition in 3 dimensions, c 2 dimensional model, d Transition temperatues

The latent energy released per molecule, $\mathbf{E}$ may be calculated using:

\begin{tabular}{|c|c|c|}
\hline H-bond length $\mathrm{h}$ & $1.75 \AA$ & Velocity of light c \\
\hline OH-bond length $b$ & $1.01 \AA$ & Molecular coordinates of ice Ic: \\
\hline o & $104.5^{\circ}$ & \\
\hline 年 & $109.5^{\circ}$ & $\Delta \mathrm{x}, \mathrm{y}=(\mathrm{b}+\mathrm{h}) \sin \left(1 / 2 \theta_{\mathrm{a}}\right)$ \\
\hline onsons & $120^{\circ}$ & $\Delta \mathrm{z}=(\mathrm{b}+\mathrm{h}) \cos \left(1 / 2 \theta_{\mathrm{g}}\right)$ \\
\hline $\begin{array}{l}\text { Dipole moment } \mu \\
\text { Dielectric const } \varepsilon\end{array}$ & $\begin{array}{l}1.27 * 10^{-29} \\
3.1\end{array}$ & Molecular coordinates of ice XIc: \\
\hline Avogadro number $\mathrm{N}$ & $6.02 * 10^{23}$ & \\
\hline Electric constant $\varepsilon_{\ell}$ & $8.85 * 10^{-12}$ & $\Delta \mathrm{x}, \mathrm{y}=\mathrm{b} \sin \left(1 / 2 \theta_{\mathrm{b}}\right)+\mathrm{h} \sin \left(1 / 2 \theta_{\mathrm{c}}\right)$ \\
\hline Planck's constant $\mathrm{h}$ & $6.63^{*} 10^{-34}$ & $\Delta \mathrm{z}=\mathrm{b} \cos \left(1 / 2 \theta_{\mathrm{b}}\right)+\mathrm{h} \cos \left(1 / 2 \theta_{\mathrm{c}}\right)$ \\
\hline
\end{tabular}

$1.27 * 10^{-29}$

3.1

$8.85 * 10^{-12}$

$6.63 * 10^{-34}$
$2.315 \AA$ $1.495 \AA$

$$
\mathrm{E}=\frac{\mu^{2}}{4 \pi \varepsilon \varepsilon_{0} \mathrm{r}^{3}}=\frac{\left(1.27 * 10^{-29}\right)^{2}}{4 \pi * 3.1 * 8.85^{*} 10^{-12 * \mathrm{r}^{3}}} \sim 22.3 \mathrm{~kJ} / \mathrm{mol}
$$

Equal to ATP's phosphodiester bond energy, wavelength $\lambda=\mathrm{h} * \mathrm{c} * \mathrm{~N} / \mathrm{E}$ :

$$
\lambda=\left(6.63 * 10^{-34}\right) *\left(3 * 10^{8}\right) *\left(6.02 * 10^{23}\right) /\left(2.23 * 10^{4}\right)=5.37 \mu
$$

This differs from the working value $4 \mu$, calling for independent scrutiny. 


\section{International Journal of Innovative Research in Medical Sciences (IJIRMS) \\ ISSN (Online): 2455-8737, page No. 160 to193 \\ Volume 01, Issue 05, July 2016}

\section{About the author}

My father was born in Glasgow in 1913. Perhaps a descendent of poet Robert Burns [2], his father sold typewriters - I touch typed as a teenager. His mother taught her children German, his brother died a prisoner of war. He collected fossils, read Geology at Cambridge and met Louis Leakey [3] while prospecting in East Africa. He studied carbonatites, carbonaceous rocks spewed up by volcanoes, from his Commonwealth Institute office. They were subducted [4] sediments containing remnants of early life. Associated phosphate deposits supported African agriculture.

My maternal grandmother was a farmer's daughter married to a boot and shoe merchant who was once Lord Mayor of Hull. Mother won $1^{\text {st }}$ class in Botany, researched polythene and her biology classes were beautifully illustrated. As a keen naturalist, she taught me to recognize birds, flowers, butterflies and fungi. She was a conscientious objector following pacifist Mahatma Ghandi and slave abolitionist David Livingstone. Her strength of character kept me innocent of WWII until entering high school.

Born $18^{\text {th }}$ March 1947, I preferred science over history, rewriting renders science truer but history false. Michael Faraday's work on electricity [5], Linus Pauling's on hydrogen bonds [6] and Charles

Darwin's on evolution [7] and their hopes for world peace inspired me; noting Francis Crick's interpretation of Rosalind Franklin's DNA diffraction patterns [8] were based on Mathematics and Physics, I studied them at Churchill College Cambridge where the Tripos system encourages multi-disciplinary education.

Crystal shapes [9] and cell contents have complex names with meaningless abbreviations. Henry Reed's Naming of parts [10] describes guns but mentions coral, gardens, bees and almond blossom; protons, neutrons and electrons don't satisfy physicists seeking the ultimate truth, concurring with Charles Dodgson [11] writing 'What I tell you three times is true' and 'I've believed as many as six impossible things before breakfast'.

All branches of science follow a common pattern, 'The exception that proves the rule' and 'A little knowledge is a dangerous thing' applying to each. An unexpected result during a physics practical class suggested ice crystallized in liquid nitrogen has great strength and changes shape. Having read Kurt Vonnegut's science fiction Cat's Cradle [12] about 'ice nine', my supervisors dismissed it as nonsense. Edwin Abbott's Flatland: a romance in many dimensions [13] describes the fate of anyone thinking 'outside the box'. Under the influence of barbiturates for toothache, I scored $4 \%$ in physics, graduating in chemistry a year later.

Frequently changing horses midstream, I next studied biochemistry at University College London, applying physics and chemistry to explain muscle contraction, contradicting Andrew Huxley's sliding filament model [14], Colin McClare [15] discussed my paper 'Electromagnetic quanta in living systems' sympathetically. Whilst training in clinical biochemistry at Surrey University, I prepared a talk on copper and zinc metabolism suggesting their roles in active transport. Eric Cundliffe [16] had introduced me to trace element complexes at Cambridge. Ideas fitting together neatly inspire generalized theories, ideas hatched in Cambridge, London and Guildford:

- Proton-ordered ice crystallized in liquid nitrogen at Earth's poles during a primordial ice age [17].

- Its ferroelectric phase transition [18] emitted infrared laser light of wavelength $4 \mu$ on cooling and 


\section{International Journal of Innovative Research in Medical Sciences (IJIRMS) \\ ISSN (Online): 2455-8737, page No. 160 to193 \\ Volume 01, Issue 05, July 2016}

- Polymerized nucleotides to form DNA including tRNA analogue 'transport DNA' explained the origin of life.

Programming an IBM 360 for local government accounting and $8 \mathrm{~K}$ PET for primary school graphics in assembler, I noted nine instructions suffice. Arguing this applied to the brain led to my 'minion' proposal, explaining how it works. I compiled a word processor, graphics package and database on a Commodore 64 and 16-bit PC to write Science Uncoiled. Professors R J P Williams and Jack Lucy refused to publish my $\mathrm{PhD}$ thesis Some Biochemical Consequences of a Consistent Framework for the Origin of Life [19].

I've researched those consequences independently [20]. Basic things have to be simple, reviewers plead not my subject, have you proved and cite referees, objecting to occult and religious

\section{References}

[1] Michael Thomas Deans, MA Cantab, MSc Lond, email: michaeltdeans@gmail.com.

[2] Robert Burns was a Scottish poet. He had a job collecting taxes and wrote poems Should old acquaintance be forgot, and never brought to mind? Should old acquaintance be forgot, and old lang syne?

For auld lang syne, my dear, for auld lang syne, we'll take a cup of kindness yet, for auld lang syne.

And surely you'll buy your pint cup! and surely I'll buy mine! And we'll take a cup o' kindness yet, for auld lang syne ...

[3] Archaeologist Louis Leakey found the skeleton of a woman he called Lucy, pioneering research on early man in the African rift valley. references, lack of empirical results and citations. My recently corroborated [21] original observation could be confirmed using available techniques, its predictions include:

- Reinterpretations of Einstein's relativity, Heisenberg's uncertainty and neural networks.

- Human-friendly, minion-based AI promises computers fostering diplomacy and world peace.

- Trace element supplementation would prevent chronic diseases and prolong lives.

Iintend resuming carpentry, ornithology, modelling and cycling and writing a sequel to 'Science Uncoiled' entitled 'Peace Building'.

about the people and places he visited. You may know Auld lang syne:

We two have run about the slopes, and picked the daisies fine;

But we've wandered many a weary foot, since auld lang syne ...

We two have paddled in the stream, from morning sun till dine $\dagger$;

But seas between us broad have roared since auld lang syne ...

And there's a hand my trusty friend! And give me a hand o' thine!

And we'll take a right good-will draught, for auld lang syne ...

[4] Carbonatites derive from limestone. When ancient creatures died, their bodies were deposited on the sea floor and turned to stone. The coastlines of North and South 


\section{International Journal of Innovative Research in Medical Sciences (IJIRMS) \\ ISSN (Online): 2455-8737, page No. 160 to193 \\ Volume 01, Issue 05, July 2016}

America match those of Europe and Africa because the continents drifted apart, "plate tectonics', riding over, 'subducting' sea floor sediments then emerging from volcanoes as carbonatites and phosphate rocks.

[5] My boyhood hero Michael Faraday lectured to children, explaining how lighthouses protected sailors, safety lamps made coal mining safer and dynamos could generate electricity for lighting and driving motors. TV broadcast of Royal Institution Christmas Lectures use his lecture room.

[6] L. Pauling (1939) The Nature of the Chemical Bond and the Structure of Molecules and Crystals, he won Nobel Prizes for Chemistry and Peace.

[7] Charles Darwin was father of evolution, his books On the origin of species and The voyage of the beagle describe its progress. His house at Down in Kent is worth visiting.

[8] J. Watson (1968) The Double helix describes how he and F. H. C. Crick analysed R. Franklin's X-ray diffraction pictures of DNA in competition with $\mathrm{L}$. Pauling. Denied a Nobel Prize, her life highlights the prejudice, cynicism and disbelief accorded to original thinkers.

[9] See any Introduction to Crystallography.

[10] His poem includes: Japonica glistens like coral ... branches hold ... silent, eloquent gestures ... blossoms are fragile and motionless ... early bees are assaulting and fumbling the flowers ... and ... almond blossom ... going backwards and forwards.

[11] C. L. Dodgson, alias Lewis Carroll (1865) Alice in Wonderland.

[12] K. Vonnegut (1963) Cat's Cradle isn't a happy story.

[13] E. A. Abbott (1884) Flatland: A Romance of Many Dimensions chronicles human scepticism; as I have, his hero took a lifetime to relate his revelation.

[14] A. F. Huxley (1954) Structural changes in muscle during contraction; interference microscopy of living muscle fibres Nature 173, 971-3, I have an autographed copy.

[15] Colin McClare was thoughtful and sympathetic, may he rest in peace.

[16] Eric Cundliffe introduced me to ionic complexes, his infectious enthusiasm persists.

[17] N. Dobretsov et al (2005) Biosphere Origin and Evolution describes Earth's primordial atmosphere.

[18] Early travellers navigated using natural magnets, lodestones, as compass needles. Natural ferroelectrics haven't been reported, ice XIc is special, ferroelectric materials release laser light during phase transitions.

[19] M. T. Deans (1988) $\mathrm{PhD}$ thesis Some biochemical consequences of a consistent framework for the origin of life.

[20] Search the internet using michaeltdeans for background details and references.

[21] F. Yen and Z. Chi (2015) Proton ordering dynamics of $\mathrm{H} 2 \mathrm{O}$ ice Phys Chem Chem Phys 17 12458-61 calculate transition temperatures for ice XIc, citing: J. D. Bernal and R. H. A. Fowler (1933), W. F. Giauque and J. W. Stout (1936), K. S. Cole and R. H. Cole (1941), N. Bjerrum (1952), L. Cooper (1956), N. Ockman (1958), Y. Tajima, T. Matsuo, H. Suga (1982), S. Kawada and H. Dohata, (1985), H. Tanaka (1998), L. Hernandez de la Peña et al (2005), N. Castro (2006), L. E. Bove et al (2009), C. Vega et al (2010), B. Pamuk et al (2012), C. Drechsel-Grau and D. Marx (2014), X. Z. Meng et al (2015), F.Yen and Z, H, Chi (2015), O. Benton, O. Sikora and N. Shannon (2015). They establish the $72 \mathrm{~K}$ phase transition. 


\section{International Journal of Innovative Research in Medical Sciences (IJIRMS) \\ ISSN (Online): 2455-8737, page No. 160 to193 \\ Volume 01, Issue 05, July 2016}

[22] Scottish polymath David Brewster, inventor of the kaleidoscope, demonstrated that light is polarized by multiple reflection.

[23] In 1932, Dutch chemist H. G. B. de Jong proposed coacervates, championed by Soviet biochemist A. I. Oparin in his book The Origin of Life.

[24] Peter D. Mitchell (1961) Coupling of phosphorylation to electron and hydrogen transfer by a chemi-osmotic type of mechanism Nature 191 (4784) 144-8 proposed protons migrated freely through cell membranes.

[25] Barrels of $\alpha$-helices are channels comprising five or more protein strands supplementing tDNAs.

[26] A. M. Turing (1950) Computing Machinery and Intelligence Mind 59 (236) 433-60, asked Can machines think?

[27] See 6.

[28] M. Chaplin's web page Water Structure and Science provides up-to-date information about ice.

[29] See 21.

[30] H. A. Krebs (1936) Intermediate Metabolism of Carbohydrates Nature 138 288-9, described the Citric acid cycle.

[31] C. McCormic (2008) Infrared deicing: giving glycol a run for its money Wings, mentioned ice forming on aircraft wings reflects $\sim 4 \mu$ light.

[32] A German pharmaceutical company sold thalidomide as a mixture of left- and righthanded forms in 1956; before its withdrawal in 1961 10,000 children were born with deformities. Since 1967, it's been used to treat leprosy. Biochemical reactions are sensitive to the handedness, chirality of chemicals.

[33] G. Wächtershäuser (1990) Evolution of the First Metabolic Cycles, PNAS 87 (1) 2004 proposed deep sea vents as a possible location for life to arise.
[34] F. Hoyle, C. Wickramasinghe and J. Watson (1986) Viruses from Space and Related Matters speculated that life arose by panspermia, living things arriving from outer space.

[35] In 1935, L. Pauling published his article The structure and entropy of ice and of other crystals with some randomness of atomic arrangement, JACS 57 (12) arguing ice retains entropy, disorder at absolute zero.

[36] In 2001, C. Leovy's review Weather and climate on Mars, Nature 412, 245-9 reported its temperature, R. Vasavada, D. A. Paige, S. E. Wood, Near-surface temperatures on mercury and the moon and the stability of polar ice deposits Icarus 141 (2) 179-93 (1999) that on Mercury and R. T. Pappalardo, W. B. McKinnon and K. K. Khurana Europa (2009) on Europa.

[37] T. Traut, Nucleotide Synthesis De Novo (2014).

[38] P. A, Küpfer and C. J. Leumann, The chemical stability of abasic RNA compared to abasic DNA Nucleic acids research 35 (1) 58-68 (2006).

[39] See 32.

[40] J. L. Sussman and S. Kim, Three dimensional structure of a transfer RNA in two crystal forms, Science 192 853-8 (1976).

[41] See 23.

[42] J. E. Hall and A. C. Guyton, Textbook of medical physiology (2006).

[43] See 25.

[44] T. W. Lyons, C. T. Rheinhard and N. J. Planapsky, The rise of oxygen in Earth's early ocean and atmosphere, Nature 506 307-15 (2014).

[45] F. Haber, Nobel lecture (1920). 


\section{International Journal of Innovative Research in Medical Sciences (IJIRMS) \\ ISSN (Online): 2455-8737, page No. 160 to193 \\ Volume 01, Issue 05, July 2016}

[46] D. Fielder, R. G. Bergman and K. N. Raymond, Stabilization of reactive organometallic intermediates inside a selfassembled nanoscale host Angewandte Chemie 45 (5) 745-8 (2006).

[47] R. Blomhoff and H. K. Blomhoff, Vitamin A isomer retinal overview of retinoid metabolism and function Journal of Neurobiology 66 (7) 606-30 (2006).

[48] R. J. Glynn et al, Effects of random allocation to vitamin E supplementation on the occurrence of venous thromboembolism: report from the Women's Health Study. Circulation. (2007).

[49] T. Heimburg and A. D. Jackson, A.D., On soliton propagation in biomembranes and nerves, PNAS 102, (2) 9790 (2005).

[50] R. Carson, Silent spring (1962).

[51] J. L. Devalia et al, Effect of nitrogen dioxide and sulphur dioxide on airway response of mild asthmatic patients to allergen inhalation, Lancet 344 (8938) 1668-71 (1994).

[52] J. C. Clifton, Mercury exposure and public health, Pediatr Clin North Am 54 (2): 237-69 (2007).

[53] J. A. Knight, Review: Free radicals, antioxidants, and the immune system, Ann Clin Lab Sci 30 (2) 145-58 (2000).

[54] WHO five a day Noncommunicable Diseases Progress Monitor ,(2015).

[55] C. Ünlü et al A systematic review of highfibre dietary therapy in diverticular disease, Int J Colorectal Dis. 27(4) 419-27 (2012).
[56] A. Malhotra, Saturated fat is not the major issue, BMJ 3476340 (2013).

[57] C. A. Francois et al, Supplementing lactating women with flaxseed oil does not increase docosahexaenoic acid in their milk, American Journal of Clinical Nutrition 77 (1) 226-233 (2003).

[58] J. R. Naylor and J. B. Young, A General Population Survey of Rest Cramps, Age Ageing 23 (5) 418-20 (1994).

[59] E. A. Guggenheim, Thermodynamics. An Advanced Treatment for Chemists and Physicists, (1985).

[60] Newton's Equal and opposite forces prevent centrioles 'pulling chromosomes apart'. Proton currents in minions create alternating magnetic fields driving chromosomes apart at cell division with frequencies determined by chromosome length.

[61] B. Banerjee et al, Effect of creatine monohydrate in improving cellular energetics and muscle strength in ambulatory Duchenne muscular dystrophy patients: a randomized, placebocontrolled 31P MRS study, Magn Reson Imaging. 28 (5) 698-707 (2010).

[62] Whether sodium ion hydrates can be as large as $\mathrm{Na}^{+} .28 \mathrm{H} 2 \mathrm{O}$ needs verification.

[63] L. Hough and J. Emsley, The shape of sweeteners to come, New Scientist 1509 (1986).

[64] My proposal that catecholamines form 4and -member rings round $\mathrm{Na}^{+}$and $\mathrm{K}^{+}$ could be tested.

[65] Larger complexes incorporating codeine or morphine block the tDNA pump, preventing pain transmission. 


\section{International Journal of Innovative Research in Medical Sciences (IJIRMS) \\ ISSN (Online): 2455-8737, page No. 160 to193 \\ Volume 01, Issue 05, July 2016}

[66] A. Cucca et al (2014) Amino acid supplementation in L-dopa treated Parkinson's disease patients, Clin Nutr. S0261-5614 (14) 00305-7.

[67] E. D. Crandall et al (1981) Effects of inhibition of $\mathrm{RBC} \mathrm{HCO3}^{-} / \mathrm{Cl}^{-}$exchange on $\mathrm{CO} 2$ excretion and downstream $\mathrm{pH}$ disequilibrium in isolated rat lungs, $\mathrm{J}$. Clin. Invest.

[68] (4) 853-62.

[69] The existence of oxygen hydrate, O2.H2O needs confirmation.

[70] Research on littoral seaweeds' resistance to tidal [O2] fluctuations might promote better treatments for thyroid disorders.

[71] See 45.

[72] Exploiting the biological facility for photolysing water would enable $\mathrm{H} 2$ fuel production.

[73] M. W. Radomski, R. M. Palmer and S. Moncada S (1987) Endogenous nitric oxide inhibits human platelet adhesion to vascular endothelium, Lancet.

[74] M. Törnqvist et al (1989) Unsaturated lipids and intestinal bacteria as sources of endogenous production of ethene and ethylene oxid, Carcinogenesis (1989) 10 (1): 39-41.

[75] D. Marine and O. P. Kimball (1921) The prevention of simple goiter in man, JAMA 77(14)1068-70.

[76] T. H. Brix, et al (2001) Evidence for a major role of heredity in Graves' disease: a population-based study of two Danish twin cohorts. J Clin Endocrinol Metab. 86(2) 930-4.

[77] P. C. Whybrow and T. Glenn (2015) Do your patients with bipolar disorder use dietary supplements? International Journal of Bipolar Disorders, 319.
[78] Roger B. Blumberg's webpage: www.mendelweb.org/homepage.html is a forum for discussing Mendelian inheritance.

[79] F. Rose (1833) On the compounds of albumin with metal oxides, Annalen der Physik und Chemie 104 132-42.

[80] A. Vitale, A. Ceriotti and J. Denecke (1993) The role of the endoplasmic reticulum in protein synthesis, modification and intracellular transport, J. Exp. Bot. 44 (9): 1417-44.

[81] P. Brazeau (1973) Hypothalamic Polypeptide That Inhibits the Secretion of Immunoreactive Pituitary Growth Hormone, Science 179 (4068) 77-9.

[82] J. R. Anderson (1999) Neurology of the pituitary gland, J Neurol Neurosurg Psychiatry, 66:703-21.

[83] A single molecular signal is amplified thrice:

- A nerve impulse reaching the hypothalamus at the centre of the brain causes one of its nine components to release 3,900 hormone molecules.

- The corresponding part of the anterior pituitary gland recognizes them, incorporating copper to 3,900 more hormones.

- Another 3,900 hormones issued by endocrine glands stimulate $3,900^{3}$ $\approx 60,000,000,000$ - all body cells.

[84] Since E. A. McCulloch and J. Till described stem cells in 1963, the possibility of growing tissues to replace a diseased organ without provoking an immune reaction has been researched.

[85] R. W. Dudek (2014) Embryology.

[86] Cyclase and kinase enzymes break different $\mathrm{Pi} \sim \mathrm{Pi}$ bonds, their reaction 


\section{International Journal of Innovative Research in Medical Sciences (IJIRMS) \\ ISSN (Online): 2455-8737, page No. 160 to193 \\ Volume 01, Issue 05, July 2016}

products cyclic AMP and GMP and PPi aren't in competition

[87] Differentiation, cell specialisation is determined by dDNAs selecting tDNAs, analogous to mRNAs selecting tRNAs in protein synthesis.

[88] K. Appel and W. Haken (1989) Every Planar Map is Four-Colorable Contemporary Mathematics 98 reported a proof of the Four colour mapping theorem.

[89] P. Kersten, P. J. White and A. Tennant in 2014 Copper bracelets and magnetic wrist straps for rheumatoid arthritis - analgesic and anti-inflammatory effects: a randomised double-blind placebo controlled crossover trial on PLoS One 9 (6).

[90] Discovered by K. Wilson (1912) Progressive lenticular degeneration: a familial nervous disease associated with cirrhosis of the liver, Brain 34 (1) 295507.

[91] Silicon hexafluoride is an inert white powder with several uses.

[92] Apatite is found in sedimentary phosphate rocks mined for phosphate fertilizer.

[93] Blue John, fluorspar, was mined during the $19^{\text {th }}$ century for purple-blue or yellow ornamental vases.

[94] R. Zang and D. P. Naughton (2010) Vitamin D in health and disease: Current perspectives, Nutrition Journal 965.

[95] R. Walsh (1981) Bond dissociation energy values in silicon-containing compounds and some of their implications, Acc. Chem. Res, 14 (8) 246-52.

[96] Their anatomical proximity and similar functions suggest this.

[97] F. Schaefer (2000) Pulsatile parathyroid hormone secretion in health and disease, Novartis Found Symp. 227 225-39.
[98] D. C. Bauer (2013) Calcium Supplements and Fracture Prevention, N Engl J Med 3691537-43.

[99] D. Winstanley et al (1998) Acid rain: Science and policy making, Environmental Science \& Policy, 151.

[100] G. M. McKhann et al (2011) The diagnosis of dementia due to Alzheimer's disease: Recommendations from the National Institute on Aging-Alzheimer's Association workgroups on diagnostic guidelines for Alzheimer's disease, Alzheimer's \& Dementia 7 (3) 263-9.

[101] B. Alberts et al (2002) The shape and structure of proteins, Molecular biology of the cell.

[102] H. \& E. Braak (1991) Neuropathological stageing of Alzheimer-related changes, Acta Neuropathologica 82 (4) 239-59.

[103] S. B. Prusiner (1997) Prion diseases and the BSE crisis, Science 278, 5336.

[104] A. B. Cummins (1960) Diatomite, in Industrial Minerals and Rocks, American Institute of Mining, Metallurgical, and Petroleum Engineers, 303-19.

[105] D. L. Godbold et al (1994) Effects of Acid Rain on Forest Processes.

[106] F. Pierre et al (1995) Effect of different exposure compounds on urinary kinetics of aluminium and fluoride in industrially exposed workers.

[107] K. Rajakumar (2003) Vitamin D, CodLiver Oil, Sunlight, and Rickets: A Historical Perspective, Pediatrics 112 (2).

[108] WHO (2004) Fluoride in Drinking-water: Background document for development of WHO Guidelines for Drinking-water Quality.

[109] J. A. Alvarez et al (2009) Dental fluorosis: Exposure, prevention and management, Med Oral Patol Oral Cir Bucal 14 (2) E103-7.

[110] See 30. 


\section{International Journal of Innovative Research in Medical Sciences (IJIRMS) \\ ISSN (Online): 2455-8737, page No. 160 to193 \\ Volume 01, Issue 05, July 2016}

[111] A. Brody (2011) Take Control of Your Blood Sugar Levels With Targeted Nutrient Compounds, Life extension magazine.

[112] R. J. Casson et al (2012) Definition of glaucoma: Clinical and experimental concepts, Clinical \& Experimental Ophthalmology 40 (4) 341-9.

[113] S. Saitoch et al (1993) Effect of a highcarbohydrate diet intake on muscle glycogen repletion after exercise in rats previously fed a high-fat diet, European Journal of Applied Physiology and Occupational Physiology, 66 (2) 127-33.

[114] T. M. Slusher (2013) Treatment of neonatal jaundice with filtered sunlight in Nigerian neonates: study protocol of a non-inferiority, randomized controlled trial, Trials 14446.

[115] A. K. Debes et al (2013) Time to initiation of breastfeeding and neonatal mortality and morbidity: a systematic review, BMC Public Health 13 (3).

[116] The phrase He was born with a silver spoon in his mouth is an oblique reference to midwive's practice of giving newborn babies a pewter spoon containing zinc to suck to ward off neonatal jaundice.

[117] C. H. Best and D. A. Scott (1923) The preparation of insulin, J Biol Chem 57 709-23.

[118] I. Quesada et al (2008) Physiology of the pancreatic $\alpha$-cell and glucagon secretion: role in glucose homeostasis and diabetes, J Endocrinol 199 5-19.

[119] J. F. Grindley (1988) Conversion of Glucose to 2-Keto-L-Gulonate, an Intermediate in L-Ascorbate Synthesis, by a Recombinant Strain of Erwinia citreus, Appl Environ Microbiol. 54(7) 1770-5.

[120] L. Hough and J.Emsley (1986) The shape of sweeteners to come, New Scientist.
[121] E. Hausmann and W. F. Neuman (1961) Conversion of proline to hydroxyproline and its incorporation into collagen.

[122] M. Bartholemew (2002) James Lind and scurvy: A revaluation. Journal for Maritime Research 4 (1) 1- 14.

[123] Pauling, L. (1970) Vitamin $C$ and the Common Cold.

[124] D. M. Gardner (1983) Development and validation of a multidimensional eating disorder inventory for anorexia nervosa and bulimia, Int J Eating Disorders 2 (2).

[125] B. L. Vallee and F. L. Hoch (1955) Zinc, a component of yeast alcohol dehydrogenase PNAS 41 (6).

[126] L. Young (2010) Recreational drugs.

[127] D. Seyferth (2001) Zinc Alkyls, Edward Frankland, and the beginnings of maingroup organometallic chemistry, Organometallics, 20 (14) 2940-55.

[128] J. Emsley (2005) The Elements of Murder : A History of Poison.

[129] Brief Overview of Human Nervous System themedicalbiochemistrypage.org.

[130] J. M. Okoh et al (1984) Chemistry of silver(I) porphyrins, Polyhedron 3 107781.

[131] The Arg2.PPi complex contains the atoms H24C12O11N8P2 needed for DNA synthesis at cell division.

[132] V. Kostenko et al (2010) Impact of silvercontaining wound dressings on bacterial biofilm viability and susceptibility to antibiotics during prolonged treatment Antimicrob Agents Chemother. 54(12) 5120-31.

[133] J. Tolonen (2010) Can You Find a Sleep Aid That Does Not Cause Brain and Liver Damage? Health and fitness.

[134] R. Klippstein (2010) Silver nanoparticles interactions with the immune system: 


\section{International Journal of Innovative Research in Medical Sciences (IJIRMS) \\ ISSN (Online): 2455-8737, page No. 160 to193 \\ Volume 01, Issue 05, July 2016}

implications for health and disease in D. P. Perez' book Silver Nanoparticles.

[135] Phosphate's roles for energy, DNA synthesis and bone and tooth maintenance are managed separately.

[136] 136 See 24.

[137] P. Mitchell (1961) Coupling of phosphorylation to electron and hydrogen transfer by a chemi-osmotic type of mechanism, Nature 191 144-148.

[138] H. Mummert, D. Gradmann (1991) Action potentials in Acetabularia: measurement and simulation of voltage-gated fluxes, J Membrane Biol 124 265-73.

[139] A. Endo (1992) The discovery and development of HMG-CoA reductase inhibitors, J Lipid Res 33 (11) 1569- 82.

[140] D. N. Skilleter and R. G. Kekwick (1971) The enzymes forming isopentenyl pyrophosphate from 5-phosphomevalonate in the latex of Hevea brasiliensis, Biochem. J. 124 407-17.

[141] V. J. J. Martin et al (2003) Engineering a mevalonate pathway inEscherichia coli for production of terpenoids, Nature Biotech. $21796-802$.

[142] G. I. Hatton (1988) Pituicytes, glia and control of terminal secretion, The Journal of experimental biology 139 67-79.

[143] Epsom cattle wouldn't drink water containing Epsom salts in 1618, H. Davy discovered Mg in 1755 and J. G. Gahn Mn in 1774, distinguishing it from $\mathrm{Mg}$. They're named after Magnesia in Greece.

[144] D. W. Russell (1992) Cholesterol biosynthesis and metabolism, Cardiovascular drugs and therapy 6 10310.

[145] D. Mozaffarian et al (2010) Effects on coronary heart disease of increasing polyunsaturated fat in place of saturated fat: review and meta-analysis of randomized controlled trials, PLoS Medicine.

[146] Low- and high- density proteins, LDLs and HDLs transport cholesterol, preventing its accumulation as the plaques which cause heart attacks and strokes.

[147] T. B. Eyl, Methyl Mercury Poisoning in Fish and Human Beings, Clinical Toxicology 4 (2) (1971).

[148] N. Bleiman and Y. G. Mishael (2010) Selenium removal from drinking water by adsorption to chitosan-clay composites and oxides: batch and columns tests, J Hazard Mater 183(1-3) 590-5.

[149] A. Haug et al (2007) How to use the world's scarce selenium resources efficiently to increase the selenium concentration in food, Microb Ecol Health Dis. 19(4) 209-28.

[150] Z. Jinsong et al (2012) Impact of heat treatment on size, structure, and bioactivity of elemental selenium nanoparticles, Int $\mathbf{J}$ Nanomedicine 7 815-25.

[151] N. S. Gavrilova et al (1998) Evolution, mutations, and human longevity: European royal and noble families, Human Biology 70 (4) $799-804$.

[152] H. Torjusen et al (2014) Reduced risk of pre-eclampsia with organic vegetable consumption: results from the prospective Norwegian mother and child cohort study, BMJ 4 (9).

[153] R. J. Seballos (2009) Cancer Screening, Disease Management.

[154] R. C. Becker (2005) Heart Attack and Stroke Prevention in Women, Circulation. 112 e273-5.

[155] Compare USGS-SGMC.kml with seer.cancer.gov.

[156] D. A Crerar and H. L. Barnes (1974) Deposition of deep-sea manganese nodules, Geochimica et Cosmochimica Acta 38 (2) 279-300. 


\section{International Journal of Innovative Research in Medical Sciences (IJIRMS) \\ ISSN (Online): 2455-8737, page No. 160 to193 \\ Volume 01, Issue 05, July 2016}

[157] S.Stoebe et al (2015) Effects of selenium supplementation on selenium status of farmed fallow deer in outdoor pens, $\mathrm{J}$ Trace Elem Med Biol 29 216-21.

[158] N. J. Beeching et al (2014) Ebola virus disease BMJ 349 g7348 (2014)

[159] A. A. Gorin (1995) B-DNA twisting correlates with base-pair morphology $\mathrm{J}$ Mol Biol 247 (1) 34-48.

[160] See 6.

[161] D. M. Phillips ed (2012) Histones and nucleohistones.

[162] D. L. Lee and R. S. Hodges (2003), Structure-activity relationships of de novo designed cyclic antimicrobial peptides based on gramicidin S, Biopolymers 71(1) 28-48.

[163] J. Soutschek (2004) et al,Therapeutic silencing of an endogenous gene by systemic administration of modified siRNAs, Nature 432 173-8.

[164] K. Luger, et al (1997) Crystal structure of the nucleosome core particle at $2.8 \AA$ resolution, Nature 389 251-60.

[165] Y. Wu and R. M. Brosh (2012) DNA helicase and helicase-nuclease enzymes with a conserved iron- sulfur cluster, Nucleic Acids Res. 40(10) 4247-60.

[166] A. M. Turing was a British computer scientist leading research in WWII.

[167] K. Fukushima (1980) Neocognitron, a selforganising neural network model for a mechanism of pattern recognition unaffected by position, Biol Cybernetics 36 193-202.

[168] T. T. Jennings (2009) Nixie Indicators and Decimal Counting.

[169] The solar cycle is the $\sim$ periodic 11 year change in the Sun's activity.

[170] The universe is approximately 13.8 billion years old.

[171] Nerve fibres resemble optic fibres, they're waveguides conducting electromagnetic waves.
[172] Having learnt my arithmetic tables, my mother's slide rule was my prize possession.

[173] Synaesthesia enables seeing sounds, tasting words or feeling a skin sensation when smelling a scent.

[174] Cardinal numbers say how many, ordinal numbers tell position.

[175] C. G. Jung (1989) I Ching or Book of Changes.

[176] C. Callendar (2010) Is Time an Illusion? Scientific American 302 (6) 40-47.

[177] Psychiatrists, psychologists and philosophers including: I. B. Myers' 16 and J. L. Holland's 6 have categorized personalities.

[178] K. Jung, father of psychology, introduced introversion and extraversion.

[179] D. Garbor received a Nobel Prize for discovering holography in 1971.

[180] Astrology is discredited by academics of all persuasions. It's consistent with numerology and has a long traditional history.

[181] The tendency for people to think of the same things as their companions may arise from the synchrony of their 'minion' clocks, aka telepathy.

[182] M. Planck introduced his constant, h, the Planck-Einstein relation using the de Broglie wavelength $\lambda$ describes a photon's energy in terms of frequency, $\lambda \nu=\mathrm{c}$. The reduced or Dirac constant $\hbar=h / 2 \pi$.

[183] W. Heisenberg introduced his uncertainty principle in 1927.

[184] Einstein's relativity was published in 1905.

[185] G. H. J. Édouard le Maître foresaw Hubble's law and proposed his Big Bang cosmology in the 1920s.

[186] The Tyger equation is a hyperbolic function similar to those for sinh and cosh.

[187] W. Blake (1794) The Tyger from his Songs of Experience. 


\section{International Journal of Innovative Research in Medical Sciences (IJIRMS) \\ ISSN (Online): 2455-8737, page No. 160 to193 \\ Volume 01, Issue 05, July 2016}

[188] In his 1927 paper, Einstein described quantum entanglement as spooky action at a distance.

[189] M. Fleischmann, S. Pons and M. Hawkins (1989) Electrochemically induced nuclear fusion of deuterium J. Electroanal. Chem., $261301-8$.

[190] My 9 plane combinations embrace Plato's perfect solids: tetrahedron, cube, icosahedron, dodecahedron and octahedron. They have 32, 8, 6, 14, 62, 20, 4, 12 and 92 faces. Combinations of these numbers explain Mendeleev's periodic table of the elements.

[191] D. I. Mendeleev's periodic table of the elements was published in 1869.

[192] C. v Weizsäcker and H. Bethe independently proposed the carbonnitrogen cycle in 1938 and 1939.

[193] A. Hewish's student J. B. Burnell discovered pulsars in 1967.

[194] William Shakespeare's Seven ages of man features in act 2, scene 7 of his play As you like it.

[195] Chaucer's Canterbury tales describe personalities in astrological terms.

[196] N. Campion (2012) Astrology and Cosmology in the World's Religions.

[197] Gray's Anatomy, now in its 40th edition, includes coloured illustrations, that current when I formulated minion logic used nine for the brain regions.

[198] B. Taylor (1989) The AB guide to music theory.

[199] Chinese tonal pronunciation invokes five tones used to add meaning and emotion to their speech.

[200] Like astrology, see 180, numerology is disregarded by scholars despite its successful manifestation in Nostradamus' prophecies.

[201] During the French revolution, Napoleon decreed a base- 10 calendar, it didn't last.

[202] Base-11 is popular with string theorists
[203] Karl Marks' Das Kapital was published in English in 1887. 